\title{
Recent advances in cobalt-, nickel-, and iron-based chalcogen compounds as counter electrodes in dye-sensitized solar cells
}

\author{
Pengkun Weia, Xue Chen a, Guizhu Wu ${ }^{a}$, Jing Li a , Yang Yang a , Zeiwei Hao a, Xiao Zhang b,*, Jing Li c,\#, \\ Lu Liu a,\$ \\ a Tianjin Key Laboratory of Environmental Remediation and Pollution Control, College of Environmental Science and Engineering, Nankai University, \\ Tianjin 300350, China \\ b Center for Aircraft Fire and Emergency, Civil Aviation University of China, Tianjin 300300, China \\ c General English Department Foreign Language College, Nankai University, Tianjin 300350, China
}

\section{A R T I C L E I N F}

\section{Article history:}

Received 27 December 2018

Accepted 15 March 2019

Published 5 September 2019

\section{Keywords:}

Counter electrode

Dye-sensitized solar cell

Chalcogen compound

Cobalt

Nickel

Iron

\begin{abstract}
A B S T R A C T
The electroactive materials used in the counter electrode (CE) are of great concern as they influence the photovoltaic performances of dye-sensitized solar cells. The main functions of CE materials are collecting electrons from the external circuit and transferring them to the electrolyte and realizing the catalytic reduction of the redox species $\left(\mathrm{I}_{3}{ }^{-}\right.$or $\left.\mathrm{Co}^{3+}\right)$ present in the electrolyte. The research hotspot of CE materials is seeking functional materials that display high efficiency, low cost, and good electrochemical stability and can substitute the benchmark platinum electrode. Chalcogen compounds of cobalt, nickel, and iron have been widely applied as CE materials and exhibit excellent electrocatalytic performances owing to their unique electrical properties, similar energies of adsorption of I atoms as platinum, excellent catalytic activities, and good chemical stabilities. In this review, we trace the developments and performances of chalcogen compounds of iron, cobalt, and nickel as CE materials and present the latest research directions for improving the electrocatalytic performances. We then highlight the optimization strategies for further improving their performances, such as fabrication of architectures, regulation of the components, synthesis of composites containing carbon materials, and elemental doping.
\end{abstract}

(C) 2019, Dalian Institute of Chemical Physics, Chinese Academy of Sciences. Published by Elsevier B.V. All rights reserved.

\section{Introduction}

With the aggravation of the energy crisis, exploitation of the clean, efficient, and sustainable solar energy has become a global research hotspot [1,2]. The solar energy-conversion technology based on photovoltaics offers a great potential solution for energy harvesting and conversion to electricity [3]. In this regard, dye sensitized solar cells (DSSCs) have been considered as one of the most promising photovoltaic technologies for realizing efficient photoelectric conversion, owing to their weak light responsiveness, environmental friendliness, and low cost of fabrication, compared with those of silicon-based photovoltaic devices [4-7]. Over the last 20 years, DSSCs have experienced qualitative leaps in their efficiency, stability, and

\footnotetext{
* Corresponding author. E-mail: xiao890829@126.com

\# Corresponding author. E-mail: victorjane@nankai.edu.cn

\$Corresponding author. E-mail: liul@nankai.edu.cn

This work was supported by the National Science Fund for Distinguished Young Scholars (21425729) from the National Natural Science Foundation of China, the National Special S\&T Project on Water Pollution Control and Treatment (2017ZX07107002),China Postdoctoral Science Foundation (2018M640209) and the Tianjin Science and Technology Support Key Projects (18YFZCSF00500).

DOI: S1872-2067(19)63361-9 | http://www.sciencedirect.com/science/journal/18722067 | Chin. J. Catal., Vol. 40, No. 9, September 2019
} 
fabrication methods. In 1991, Grätzel et al. [8] coated colloidal $\mathrm{TiO}_{2}$ films with a monolayer of a charge-transfer dye for light harvesting that yielded a power conversion efficiency (PCE) of 7.12\% under simulated solar light irradiation. In addition, his group in 2011 enhanced the performance of DSSCs by obtaining a PCE of $12.3 \%$ through incorporation of a $\mathrm{Co}^{(\mathrm{II} / \mathrm{III})}$ tris(bipyridyl)-based redox electrolyte in conjunction with a custom synthesized donor-p-bridge-acceptor zinc porphyrin dye as the sensitizer [9]. Afterwards, in 2017, they improved the performance of DSSCs to a new high by radically improving the PCE to $28.9 \%$ under indoor conditions at 1000 lux [10]. The most common PCE values of recently reported DSSC devices exceed 10\%, and have been obtained through significant improvements in the dye, electrolyte, and counter electrode (CE) materials.

Typically, a DSSC device is composed of a nanocrystalline semiconductor oxide, which serves as the photoanode, the CE, a dye molecule, and a redox electrolyte [11-14]. The main function of each component is as follows. The dye molecule works as a sensitizer that absorbs the solar radiation and injects photoexcited electrons into the conduction band of the semiconductor oxide, which leaves the dye in its oxidized state; the injected electrons transfer from the semiconductor to an FTO conductive glass and the external circuit, which requires appropriate band structure for the semiconductor oxide. The electroactive materials in the CE collect the electrons from the external circuit and transfer them to the electrolyte to realize the catalytic reduction of the redox species $\left(\mathrm{I}_{3}{ }^{-}\right.$or $\left.\mathrm{Co}^{3+}\right)$ present in the electrolyte. The electrolyte is responsible for donating electrons and reducing the oxidation state of the dye, which ensures that the dye returns to the ground state.

Based on the abovementioned fundamental processes of DSSCs, the CE is the critical component that mainly promotes charge transfer and catalyzes the reduction reaction of the redox species, which belongs to the category of heterogeneous catalytic reactions occurring at the solid CE material-liquid electrolyte interface. These processes are of great concern for the effective utilization of photogenerated electrons in the catalytic reduction of the electrolyte molecules, and specifically influence the PCEs of DSSCs through the short-circuit current $U_{\mathrm{sc}}$ ) and fill factor (FF) [15]. In order to obtain high photovoltaic performances, CE materials should display the following properties.

(1) High electron conductivity and excellent diffusion ability. The diffusion of electrolyte molecules and the charge transfer occurring in CE materials are crucial processes of the electrocatalytic reaction involving the CE. Therefore, CE materials should allow fast electron transfer and provide ion-diffusion channels.

(2) High catalytic activity for the reduction of the electrolyte molecule. A high catalytic activity increases the overall reaction rate and improves the current density of DSSC devices. Furthermore, the highly efficient catalytic effect can inhibit adverse reactions and polarization.

(3) Appropriate band structure to improve the exchange current at the CE material/electrolyte interface, where the energy levels of the CE materials overlap with those of the redox electrolyte. The optimal condition is that the conduction band and valence band of the CE material both contribute to the energy overlaps with the redox species.

(4) Good electrochemical stability to avoid becoming inactive and be decomposed to harmful byproducts within the potential range of DSSCs.

Platinum coated on conductive glass is the benchmark electrode, however, its high cost and scarce resources severely hinder the commercial development and practical application of DSSCs [16-19]. Recently, various kinds of non-noble functional materials have been explored to develop platinum-free or low-platinum CE materials [20]. Particularly, chalcogen compounds of cobalt, nickel, and iron (CCNI) display unique electrical properties, similar adsorption energies of I atoms as platinum, excellent catalytic activities, and good chemical stabilities. These materials were primitively developed as CE electrocatalysts by Grätzel et al. [21]. In 2009, Grätzel's group electrochemically deposited CoS nanoparticles on flexible ITO/PEN films that yielded the same efficiency of $6.5 \%$ as that obtained with platinum CE. Subsequently, the NiS CE fabricated by Meng's group presented a performance (6.82\%) comparable to that of platinum CE (7.00\%). Motivated by their findings, sulfides and selenides of iron, cobalt, and nickel have been intensively studied and their great potentials as low-cost high-efficiency CE materials demonstrated in the forms of $\mathrm{FeS}_{2}$,

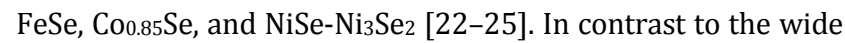
application of sulfides and selenides, oxides of iron, cobalt, and nickel have been rarely studied. The electrocatalytic potential of $\alpha-\mathrm{Fe}_{2} \mathrm{O}_{3}$ for reducing $\mathrm{I}_{3}{ }^{-}$was determined by Yang's group by using first-principle calculations [26], however, the follow-up studies have focused on the sulfides and selenides. Very recently, Li's group reported that $\mathrm{Fe}_{3} \mathrm{O}_{4}$ /nitrogen-doped graphene and $\mathrm{Co}_{3} \mathrm{O}_{4}$ on reduced graphene oxide (RGO) nanosheets display better performances than the platinum CE [27-29]. Apart from monometallic chalcogenides, binary and ternary CCNI have equally gained prominence as a class of CE materials for DSSCs owing to their unique electrochemical properties. By modulating the chemical composition, ternary and polyphyletic

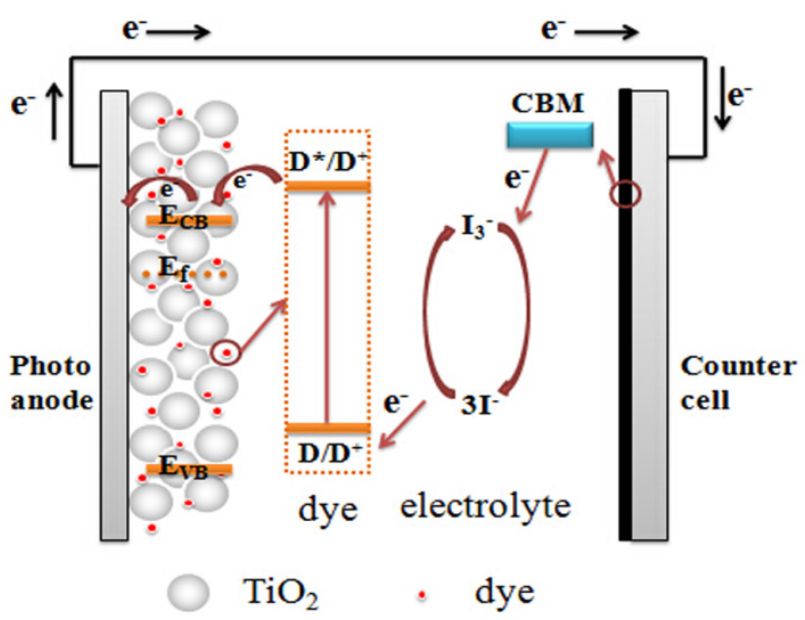

Fig. 1. Components and fundamental processes of dye-sensitized solar cells. Reproduced from ref. [15]. 
compounds based on iron, cobalt, and nickel, such as NiCoSe, $\mathrm{Co}-\mathrm{Fe}-\mathrm{Se} / \mathrm{S}$, and $\mathrm{NiCo}_{2} \mathrm{O}_{4}$, can reveal promising electronic conductivity and intrinsic catalytic activity [30-32].

Herein, we review the research progress of CCNI as CE materials of DSSCs. Particularly, the electrocatalytic performances of their oxides, sulfides, and selenides were compared based on extensive review of the relevant literature. Furthermore, we highlight the high performances of multi-metallic compounds of iron, cobalt, and nickel, which are attributed to the unique coexistence of two different cations in a single crystal structure. Subsequently, we trace the strategies adopted for optimizing the electrocatalytic performance by mainly focusing on the fabrication of architectures, regulation of the components, synthesis of composites containing carbon materials, and elemental doping.

\section{Monometallic cobalt-based compounds}

\subsection{Pure cobalt-based compounds}

The series of transition metals have increasingly attracted the geometric attention of researchers as alternative CE materials. Among them, iron, cobalt, and nickel have been particularly studied through consideration of their distinctive electrochemical properties, various compositions, and abundant and lost-cost feedstock. A number of photovoltaic parameters of DSSCs based on CCNI are summarized in Table 1. In 2009, Zakeeruddin's group [21] designed for the first time CoS nanoparticles loaded on ITO/PEN films as the CE by using electrochemical deposition method, and obtained a PCE of $6.5 \%$, which is comparable to that of platinum/ITO/PEN CE in IL-based DSSCs using Z907 as the sensitizer and a eutectic melt as the electrolyte, and demonstrated prominent stability of the cell under extended illumination and thermal stress. Inspired by the breakthrough, a number of studies that utilized cobalt sulfide as the CE have been reported. Chang et al. [33] synthesized $\mathrm{Co}_{9} \mathrm{~S}_{8}$ nanocrystals by a one-step non-injection method, which were then deposited on substrates as the CE of DSSCs. As shown in Fig. 2, the morphological, photoelectrical, and electrochemical characteristics were measured. Notably, the DSSC fabricated with $\mathrm{Co}_{9} \mathrm{~S}_{8} \mathrm{CE}$ revealed a lower average efficiency of $7.02 \%$, compared to that of a DSSC equipped with platinum CE (7.2\%). Shrestha and colleagues [34] reported a solution chemical transformation strategy based on mediated ion exchange to synthesize various $1 \mathrm{D} \mathrm{CoS}_{1.0365}$ nanorods with porous structures as CEs, and obtained a PCE of $7.4 \%$, which is lower than that of a standard platinum CE (7.7\%).

In comparison to metal sulfides, metal selenides exhibit smaller electronegativity metallicity, which is attributed to the increased electrical conductivity and intrinsic catalytic property [35]. Hence, Wang and coworkers [24] fabricated graphene-like $\mathrm{Co}_{0.85} \mathrm{Se}$ hybrid on FTO by using a one-pot hydrothermal approach. The PCE of the DSSC based on $\mathrm{Co}_{0.85} \mathrm{Se}$ CE was $9.40 \%$, which was higher than that of the cell with platinum CE (8.64\%). However, the relatively weak junction between cobalt selenide and the electrolyte will reduce the transfer rate of electrons from the external circuit to the interface,
Table 1

Photovoltaic parameters of the DSSCs based on monometallic cobalt-, nickel-, or iron-based compound CEs.

\begin{tabular}{|c|c|c|c|c|c|c|}
\hline CE material & $\begin{array}{c}J_{\mathrm{sc}} \\
\left(\mathrm{mA} \mathrm{cm}^{-2}\right)\end{array}$ & $\begin{array}{l}V_{\text {oc }} \\
(\mathrm{V})\end{array}$ & $\mathrm{FF}$ & $\begin{array}{l}\text { PCE } \\
(\%)\end{array}$ & $\begin{array}{l}R_{\mathrm{ct}} \\
(\Omega)\end{array}$ & Ref. \\
\hline $\mathrm{CoS}$ & 11.91 & 0.75 & 0.73 & 6.5 & 1.8 & {$[21]$} \\
\hline CoS nanorods & 16.31 & 0.71 & 066 & 7.67 & 1.25 & [56] \\
\hline $\mathrm{CoS}_{2}$ nanoflakes & 10.13 & 0.747 & 0.688 & 5.20 & - & [57] \\
\hline $\mathrm{Co}_{9} \mathrm{~S}_{8}$ & 14.21 & 0.71 & 0.69 & 7.00 & 0.13 & [33] \\
\hline $\operatorname{CoS}_{1.0365}$ nanorods & 18.06 & 0.65 & 0.65 & 7.40 & - & [34] \\
\hline $\operatorname{CoS}_{x}$ & 16.8 & 0.73 & 0.70 & 8.48 & 0.78 & [53] \\
\hline $\mathrm{Co} 0.85 \mathrm{Se}$ & 16.8 & 0.742 & 0.67 & 8.30 & 3.3 & [36] \\
\hline $\mathrm{Co}_{0.85} \mathrm{Se}$ & 16.98 & 0.738 & 0.75 & 9.40 & 0.6 & [24] \\
\hline $\mathrm{CoSe}_{2}$ nanorods & 18.55 & 0.753 & 0.73 & 10.20 & 1.4 & [58] \\
\hline $\mathrm{Co}_{3} \mathrm{O}_{4} @ \mathrm{RGO}$ & 11.91 & 0.79 & 0.62 & 5.79 & 1.26 & [29] \\
\hline CoS on FGNS & 12.91 & 0.67 & 0.64 & 5.54 & 1.79 & [46] \\
\hline $\mathrm{CoS} / \mathrm{rGO}_{0.10}$ & 14.91 & 0.76 & 0.75 & 8.38 & 2.71 & [44] \\
\hline $\mathrm{CAN}-\mathrm{CoS}_{2}$ & 16.51 & 0.76 & 0.71 & 8.92 & 6.44 & [41] \\
\hline NDG/CoS & 20.38 & 0.71 & 0.74 & 10.71 & 2.58 & [45] \\
\hline $\mathrm{Co}_{3} \mathrm{~S}_{4} / \mathrm{Co}_{3} \mathrm{O}_{4}$ & 17.99 & 0.67 & 0.71 & 8.6 & 4.8 & {$[54]$} \\
\hline S-doped $\mathrm{Co}_{3} \mathrm{O}_{4}$ & 16.83 & 0.70 & 0.66 & 7.79 & - & [59] \\
\hline $\mathrm{CoSe}_{2} / \mathrm{CoSeO}_{3}$ & 15.88 & 0.81 & 0.71 & 9.27 & 3.56 & [55] \\
\hline NiS nanosheets & 13.0 & 0.76 & 0.72 & 7.08 & 1.73 & [60] \\
\hline$\alpha-\mathrm{NiS}$ & 15.80 & 0.73 & 0.64 & 7.33 & 5.45 & [61] \\
\hline $\mathrm{NiS}$ & 18.71 & 0.74 & 0.63 & 8.62 & 2.22 & [62] \\
\hline $\mathrm{NiS}_{2}$ cubes & 12.62 & 0.715 & 0.60 & 5.43 & 9.86 & [63] \\
\hline NiS & 16.79 & 0.74 & 0.59 & 7.37 & 1.63 & [64] \\
\hline $\mathrm{NiS}_{2}$ microspheres & 17.48 & 0.71 & 0.63 & 7.84 & 9.68 & [65] \\
\hline $\mathrm{Ni}_{3} \mathrm{~S}_{2} / \mathrm{MWCNT}-\mathrm{NC}$ & 13.96 & 0.77 & 0.63 & 6.87 & 9.11 & [66] \\
\hline $\mathrm{NiS} / \mathrm{Cc}$ & 18.18 & 0.76 & 0.59 & 8.15 & 7.25 & [67] \\
\hline NiO@SiNW-C & 18.52 & 0.759 & 0.675 & 9.49 & 0.07 & [68] \\
\hline $\mathrm{NiS} / \mathrm{rGO}$ & 16.35 & 0.75 & 0.78 & 9.5 & 1.5 & [69] \\
\hline S-NiO & 13.5 & 0.77 & 0.48 & 5.04 & - & [70] \\
\hline $\mathrm{Ni}_{3} \mathrm{~S}_{2} / \mathrm{Ni}-\mathrm{P}$ & 13.62 & 0.729 & 0.63 & 6.28 & 1.95 & [71] \\
\hline Ni@NiS & 15.36 & 0.76 & 0.68 & 7.84 & 2.65 & [72] \\
\hline $\mathrm{Ni}-\mathrm{NiS}$ & 16.26 & 0.80 & 0.66 & 8.55 & 1.00 & [73] \\
\hline $\mathrm{NiS} / \mathrm{Ni}_{3} \mathrm{~S}_{2}$ nanorods & 15.33 & 0.71 & 0.66 & 7.20 & 1.36 & [74] \\
\hline $\mathrm{NiSe}-\mathrm{Ni}_{3} \mathrm{Se}_{2} / \mathrm{RGO}$ & 16.31 & 0.75 & 0.64 & 7.83 & 0.68 & [25] \\
\hline $\mathrm{NiSe}_{2} / \mathrm{RGO}$ & 17.15 & 0.76 & 0.60 & 7.76 & 1.52 & [75] \\
\hline$\alpha-\mathrm{Fe}_{2} \mathrm{O}_{3}$ & 15.92 & 0.78 & 0.56 & 6.96 & 2.3 & [26] \\
\hline $\mathrm{Fe}_{3} \mathrm{O}_{4}$ & 16.67 & 0.69 & 0.63 & 7.65 & 4.30 & [76] \\
\hline FeS nanorods & 14.00 & 0.67 & 0.63 & 6.47 & 2.32 & [77] \\
\hline FeSe & 17.10 & 0.73 & 0.61 & 7.64 & 4.90 & [23] \\
\hline $\mathrm{FeSe}_{2}$ nanosheets & 17.49 & 0.72 & 0.60 & 7.53 & 0.53 & [78] \\
\hline Flower-like $\mathrm{FeSe}_{2}$ & 14.93 & 0.74 & 0.72 & 8.00 & 0.53 & [79] \\
\hline $\mathrm{FeSe}_{2}$ microspheres & 16.14 & 0.74 & 0.70 & 8.39 & 0.49 & [80] \\
\hline $\mathrm{FeSe}_{2}$ clusters & 16.06 & 0.75 & 0.74 & 9.01 & 0.18 & [81] \\
\hline Rosin carbon $/ \mathrm{Fe}_{3} \mathrm{O}_{4}$ & 16.01 & 0.75 & 0.68 & 8.11 & 1.09 & [82] \\
\hline $\mathrm{Fe}_{3} \mathrm{O}_{4} / \mathrm{RGO}$ & 24.45 & 0.76 & 0.32 & 5.91 & 340 & [83] \\
\hline $\mathrm{HCCMS} / \mathrm{Fe}_{3} \mathrm{O}_{4} @ \mathrm{~N}-\mathrm{RGO}$ & 17.8 & 0.795 & 0.70 & 9.89 & 0.12 & [27] \\
\hline
\end{tabular}

thus lowering the catalytic activity. In addition, the cobalt-selenium alloy was fabricated by Duan et al. [36] on FTO with high optical transparency and electrocatalytic activity by using a mild solution strategy, and it was found that cobalt-selenium hybrids display lower electrical resistances and better electrocatalytic properties than pure cobalt and selenium. 
(a)

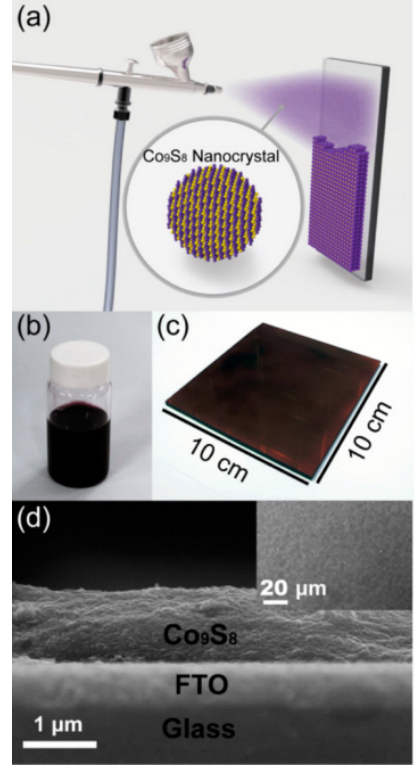

(e)
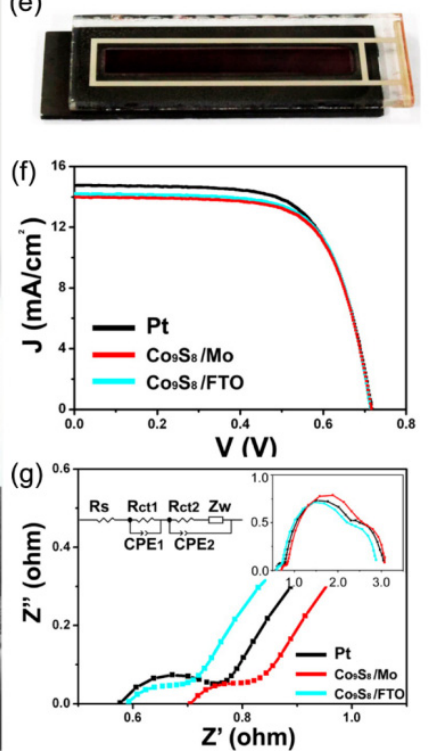

Fig. 2. (a) Schematic diagram of $\mathrm{Co}_{9} \mathrm{~S}_{8}$ nanocrystals synthesized on FTO by spray deposition; (b) Photograph of $\mathrm{Co}_{9} \mathrm{~S}_{8}$ nanoink used for the thin film deposition; (c) Photograph of the $\mathrm{Co}_{9} \mathrm{~S}_{8}$ nanocrystal thin film deposited on a $10 \mathrm{~cm} \times \times 10 \mathrm{~cm}$ FTO substrate; (d) SEM image of the cross-sectional and plan (inset) views of the $\mathrm{Co}_{9} \mathrm{~S}_{8}$ film/FTO; (e) Photograph of a simulated DSSC cell with $2 \mathrm{~cm}^{2}$ working area; (f) Photocurrent density-voltage plots of DSSCs based on platinum, $\mathrm{Co}_{9} \mathrm{~S}_{8}$ on FTO, and $\mathrm{Co}_{9} \mathrm{~S}_{8}$ on Mo CEs obtained under AM1.5 illumination; (g) Nyquist curves of the DSSCs based on platinum, $\mathrm{Co}_{9} \mathrm{~S}_{8}$ on FTO, and $\mathrm{Co}_{9} \mathrm{~S}_{8}$ on Mo CEs. Reproduced from ref. [33].

\subsection{Composites of pure cobalt-based compounds and carbon materials}

Although cobalt oxides have been widely applied in electrocatalytic reactions [37], supercapacitors [38], and lithium ion batteries [39] owing to their excellent electrochemical capacity and stability, there are few reports on their use as the CE of DSSCs. Li and coworkers [29] fabricated a nanocomposite of porous $\mathrm{Co}_{3} \mathrm{O}_{4}$ nanoflakes and RGO by using the simple hydrothermal reduction method. The addition of RGO dramatically enhanced the electrochemical activity and stability of $\mathrm{Co}_{3} \mathrm{O}_{4}$ nanoflakes. The PCE of the DSSC based on $\mathrm{Co}_{3} \mathrm{O}_{4} / \mathrm{RGO}$ CE (5.79\%) was remarkably higher than those of the cells with pure $\mathrm{Co}_{3} \mathrm{O}_{4}$ or RGO CE and even comparable to that a cell using platinum CE (6.16\%). The investigation revealed that composites of cobalt oxides and carbon materials have potential as CE materials for DSSCs.

Recently, researchers have studied composites of cobalt sulfide and conducting materials. Various carbon materials have been the focus of subsequent research owing to their high electroconductivity, low production cost, and excellent stability. Many researchers have revealed that the addition of carbon materials remarkably improved the electrocatalytic activity towards the reduction of triiodide, resulting in a better PCE than the pure material [40-47]. A range of $\mathrm{CoS}_{2}$-embedded carbon nanocages were engineered for various heating times by Wang and coworkers [40] through a simple wet method by using ZIF-67 metal-organic framework as a template. The re-

sultant composite was successfully applied in DSSCs as the CE, and yielded a higher PCE (8.20\%) than the DSSC equipped with platinum CE (7.88\%). The researchers ascribed the improvement in the PCE to the interactions between $\mathrm{CoS}_{2}$ nanoparticles and carbon nanocages, which resulted in higher electrocatalytic property and better electroconductivity and stability. Subsequently, Qian and coworkers [41] further studied the transformation process of ZIF-67 into cobalt sulfides, and synthesized a series of yolk-shell CoS-C@CoS, CoS $2-\mathrm{C} @ \mathrm{CoS}_{2}$, and $\mathrm{CoS} / \mathrm{CoS}_{2}-\mathrm{C}$ by adjusting the sulfidation progress. Owing to their remarkable structural features and excellent chemical compositions, the yolk-shell composites revealed outstanding electrical conductivity and prominent electrocatalytic activity. The DSSC based on $\mathrm{CoS}_{2}-\mathrm{C} @ \mathrm{CoS}_{2} \mathrm{CE}$ displayed the highest PCE of $9.32 \%$, which was remarkably higher than that of a cell utilizing platinum CE (8.24\%). In view of the high carrier mobility, absence of a bandgap, and high specific surface area, graphene can accelerate charge transfer and improve catalytic properties. These remarkable advantages indicate that graphene can be used as a scaffold to facilitate the advancement of cobalt sulfides as CEs for DSSCs. Moreover, the composite of CoS and rGO was prepared on FTO films via electrophoretic deposition, as well as through ion exchange deposition, which was followed by solution treatment of sodium borohydride and sulfuric acid [43]. The introduction of rGO enhanced the charge transfer and electrocatalytic activity for the reduction of triiodide. Compared with that of a cell using platinum CE, the DSSC fabricated with the optimal CoS/rGO yielded an increase in PCE of $27.93 \%$. In addition, researchers subsequently fabricated a $\mathrm{CoS} / \mathrm{rGO}$ film with a thickness of $72 \mathrm{~nm}$ on FTO by using facile hydrothermal method [44]. The resultant CoS/rGO revealed excellent conductivity and remarkable catalytic activity, which could be ascribed to the synergistic effect between $\mathrm{rGO}$ and CoS. The DSSC equipped with CoS/rGO CE exhibited a higher PCE of $9.82 \%$, compared with that of a cell employing platinum CE. Chen's group [45] designed and synthesized nitrogen-doped graphene/cobalt sulphide (NDG/CoS) by using ammonia as the nitrogen source through solvothermal method. The approximate core-shell NDG/CoS exhibited excellent electrocatalytic activity and electroconductivity, which could be attributed to a synergic effect between the inner cobalt sulfide and the outer nitrogen-doped graphene. Ultimately, the NDG/CoS enabled the DSSC to display the highest PCE of $10.71 \%$. The simple and novel protocol would provide a new strategy for promoting the development of platinum-free CEs.

Owing to the high electrocatalytic activity of CoSe nanoparticles and fast charge transport in graphene, Angaiah and colleagues [48] utilized the simple hydrothermal method to synthesize nanocomposites by growing CoSe on different amounts of graphene nanosheets. They revealed that the electrochemical and photovoltaic performances of the nanocomposites can be regulated by altering the amount of graphene. By comparison, there would be restacking of graphene, which resulted in a lower electrocatalytic activity of CoSe/GN nanocomposites, while the mass ratio of graphene to CoSe was greater than 0.5:1. Owing to the synergetic effect between CoSe nanoparticles and graphene, the PCE of the DSSC based on CoSe/GN 0.5 CE 
was $9.27 \%$, which is an increase of $20 \%$, compared with that of the device with platinum CE (7.68\%). Then, three composites of $\mathrm{CoSe}_{2}$ and carbon were prepared by Ho's group [49] on FTO through two-pot synthesis (involving pulse-potential deposition method and annealing technique). After calcination, the nanoclimbed-wall-like $\mathrm{CoSe}_{2} / \mathrm{C}$ ( $\mathrm{CoSe}_{2} / \mathrm{C}$-NCW) films exhibited high conductivity and catalytic activity for triiodide reduction, and yielded a PCE of $8.92 \%$, which was higher than that of platinum (8.25\%). To further improve the electrocatalytic performance of $\mathrm{CoSe}_{2} / \mathrm{C}-\mathrm{NCW}$, the product was subsequently electrodeposited on carbon cloth (CC) and nickel foam (NF). Compared with the DSSC based on $\mathrm{CoSe}_{2} / \mathrm{C}$-NCW CE, the devices with $\mathrm{CoSe}_{2} / \mathrm{C}-\mathrm{NCW}$ on $\mathrm{CC}$ and NF realized higher efficiencies of $9.87 \%$ and $10.46 \%$, respectively.

\subsection{Doping of external elements into cobalt-based compounds}

Of late, the central task in the development of DSSCs based on platinum-free electrocatalysts that exhibit high performances has been exploring feasible high-efficiency methods for the introduction of external elements containing rich electrocatalytically active sites [50]. The amount of dopant has a huge impact on the abundance of active sites in the resultant materials [51]. In addition, it is the active sites at the surface, instead of the major sites, that determine the activities of electrolytic materials [52]. The development of $\mathrm{Co}_{3} \mathrm{O}_{4}$ as the CE of DSSCs is vastly hindered by its relatively low activity, which is a result of the high interfacial charge resistance encountered during the $\mathrm{I}_{3}{ }^{-}$reduction process. Therefore, elemental sulfur was successfully doped into $\mathrm{Co}_{3} \mathrm{O}_{4}$ nanosheets by the facile vapor-phase hydrothermal method [53]. The resultant sulfur-doped $\mathrm{Co}_{3} \mathrm{O}_{4}$ containing $47 \%$ of sulfur at the surface still maintained the bulk structures of $\mathrm{Co}_{3} \mathrm{O}_{4}$. The DSSC employing the sulfur-doped $\mathrm{Co}_{3} \mathrm{O}_{4} \mathrm{CE}$ yielded a significantly higher PCE $(7.79 \%)$ than that using $\mathrm{Co}_{3} \mathrm{O}_{4} \mathrm{CE}(0.33 \%)$, which is comparable to that of the cell utilizing platinum CE (7.81\%). Subsequently, Wang's group [54] synthesized $\mathrm{Co}_{3} \mathrm{~S}_{4} / \mathrm{Co}_{3} \mathrm{O}_{4}$ through a wet ion-exchange reaction. After the rapid sulfurization process, the inert surface of $\mathrm{Co}_{3} \mathrm{O}_{4}$ was activated into the active $\mathrm{Co}_{3} \mathrm{~S}_{4}$, which increased its adsorption energy $\left(E_{\mathrm{ad}}^{\mathrm{I}}=0.347 \mathrm{eV}\right)$ to $0.835 \mathrm{eV}$. The short sulfurization reaction remarkably improved the conductivity and electrocatalytic performance for the $\mathrm{I}_{3}{ }^{-}$reduction of $\mathrm{Co}_{3} \mathrm{O}_{4}$. Notably, the $\mathrm{Co}_{3} \mathrm{O}_{4} \mathrm{CE}$ with an activation time of $30 \mathrm{~s}$ displayed a PCE of $8.6 \%$, which is similar to that a cell involving platinum CE (8.6\%). The report presented a novel and convenient method to modify the surface of inert metal oxides by regulating the absorption energy.

Over the last few years, CoSe-based compounds have been testified as effective and inexpensive CE materials of DSSCs owing to their outstanding catalytic properties towards the reduction of $\mathrm{I}_{3}^{-}$[23]. Recently, CoSe-based materials containing various phases of two components have been designed and studied. For example, synthesis of a hybrid of $\mathrm{CoSe}_{2}$ and $\mathrm{CoSeO}_{3}$ $\left(\mathrm{CoSe}_{2} / \mathrm{CoSeO}_{3}\right)$ was presented by Ho and coworkers [55]. By adding various surfactants with different surface charges, diverse morphologies of $\mathrm{CoSe}_{2} / \mathrm{CoSeO}_{3}$ composite were obtained. Owing to electrostatic adsorption involving the reactant pre- cursor and the micelle, the surface charge of the surfactant tremendously affected the distribution of the cobalt and selenium ions, which determined the nanocrystal growth. As the CE of DSSCs, the $\mathrm{CoSe}_{2} / \mathrm{CoSeO}_{3}$ fabricated by adding Triton X-100 (non-ionic surfactant) exhibited the highest PCE of 9.27\%, which is superior to that of a cell employing platinum CE (7.91\%). The report could not only confirm the excellent catalytic activity of $\mathrm{CoSe}_{2} / \mathrm{CoSeO}_{3}$, which could replace the precious platinum in the CEs of DSSCs, but also broaden the application scope of DSSCs.

\section{Monometallic nickel-based compounds}

\subsection{Pure nickel-based compounds}

Owing to their comparatively lower electrochemical properties, there are few reports on the use of nickel oxides as CEs in DSSCs. Dini's group [84] synthesized and applied $\mathrm{NiO}$ as the CE for DSSCs. However, the PCE of the DSSC with NiO CE was only $0.022 \%$. To further popularize the application of DSSCs, numerous attempts have been made to explore nickel sulfides as the CEs in DSSCs, owing to their simple fabrication, low cost, and high electrocatalytic activity [60-65,85-89]. Nickel sulfide (NiSPR) was synthesized on FTO by Luo et al. [85] via the simple cyclical potential reversal method. For the first time, nickel sulfides were applied in DSSCs as the CEs. Notably, the DSSC based on the NiSPR CE exhibited a PCE of $6.82 \%$, which was slightly lower than that of a cell based on platinum CE (7.00\%). This research opened up the possibility of widening the application of transition metals as CE materials for DSSCs. As a consequence, the development of nickel sulfides as the CEs in DSSCs has been a hot research area. Pan's group [61] prepared $\alpha$-NiS nanocrystals of various sizes through a liquid-phase technique by adjusting the reaction temperature. Owing to the excellent surface effect and work function of a $\alpha$-NiS nanocrystal with a small size, the cell with monodisperse $\alpha$-NiS CE exhibited an obviously higher PCE of 7.33\% than a cell employing bulk NiS (4.64\%). Xiao and coworkers [64] reported on the synthesis of nanoporous NiS via CV deposition, which was followed by $\mathrm{H}_{2} \mathrm{~S}$ hydrothermal treatment. They found that the electrocatalytic activity of $\mathrm{NiS}$ could be reduced, owing to the existence of $\mathrm{Ni}(\mathrm{OH})_{2}$ and nickel. During the $\mathrm{H}_{2} \mathrm{~S}$ hydrothermal treatment, the purity of NiS increased, which improved the electrocatalytic properties. Benefiting from the high purity and porous structure, the PCE of the DSSC based on the pure NiS CE (7.37\%) was significantly higher than that involving a product without $\mathrm{H}_{2} \mathrm{~S}$ treatment (4.84\%). Without further post-treatment, Wei and coworkers [60] studied NiS nanosheets grown on ITO as the CE of DSSCs. The NiS deposited on ITO revealed great electron conduction and catalytic activity owing to the increased light absorbance, which can be attributed to the mirror effect, and the close contact with the ITO. Although the PCE of the DSSC based on the as-fabricated NiS CE was slightly higher than that the cell based on platinum CE (7.01\%), the value could only reach $7.08 \%$.

In view of the low cost, high electrochemical properties, and formation of various compounds, nickel selenides, such as NiSe, 
$\mathrm{Ni}_{3} \mathrm{Se}_{4}, \mathrm{NiSe}_{2}$, and $\mathrm{Ni}_{0.85} \mathrm{Se}$, have been regarded as potential alternative materials to platinum as the CE of DSSCs [75,90-92]. NiSe nanomaterials with different morphologies were synthesized by Fan's group [93] via the simple hydrothermal approach by controlling the amounts of the various source materials and the reaction time. Electrochemical measurements indicated that the NiSe nanoparticles (NiSe-1) yielded significantly better electron conduction and electrocatalytic activity than micro and submicron particles (NiSe-2), owing to their small and uniform sizes. With the NiSe-1 CE, the DSSC displayed a higher PCE (7.82\%) than those employing the NiSe-2 CE (6.90\%) and platinum CE (7.62\%). Lee et al. [94] designed and prepared $\mathrm{Ni}_{3} \mathrm{Se}_{4}$ with distinct hollow constructions by using various organic solvents, including methanol ( $\left.\mathrm{Ni}_{3} \mathrm{Se}_{4} @ \mathrm{MeOH}\right)$, ethanol ( $\left.\mathrm{Ni}_{3} \mathrm{Se}_{4} @ \mathrm{EtOH}\right)$, and propan-1-ol ( $\mathrm{Ni}_{3} \mathrm{Se}_{4} @$ n-PrOH). By contrast, the polarity of the solvent positively correlated with the roughness and surface area of the resultant $\mathrm{Ni}_{3} \mathrm{Se}_{4}$. As a consequence, the urchin-like $\mathrm{Ni}_{3} \mathrm{Se}_{4} @ \mathrm{MeOH}$ CE revealed the highest PCE of 8.31\% among them, which is even superior to that of platinum CE (8.03\%). Wang's group [95] successfully applied for the first time the octahedral $\mathrm{NiSe}_{2}$ fabricated through the facile one-pot hydrothermal method as the CE in DSSCs; the material exhibited excellent electrocatalytic activity for triiodide reduction. The PCE of the DSSC based on $\mathrm{NiSe}_{2}$ CE reached $8.69 \%$, which is superior to that of a cell utilizing platinum CE (8.04\%). As an important member of nickel selenides, $\mathrm{Ni} 0.85 \mathrm{Se}$ has been considered as an alternative to platinum as the CE material of DSSCs because of its specific stoichiometry and unique electronic configuration. Hence, our group [96] fabricated mesoporous $\mathrm{Ni}_{0.85} \mathrm{Se}$ spheres assembled with particles by a facial solvothermal approach. Electrochemical measurements indicated that Nio.85Se exhibited high electrical conductivity and electrocatalytic performance, and yielded a PCE of $7.24 \%$, which is comparable to that of platinum (7.56\%).

\subsection{Composites of pure nickel-based compounds and carbon materials}

Mahajan et al. [97] fabricated the composite of $\mathrm{NiO}$ nanoparticles and rGO to improve the efficiency, but the DSSC based on $\mathrm{rGO} / \mathrm{NiO} \mathrm{CE}$ still yielded a low PCE of 3.69\%. Many researchers have studied composites of nickel sulfides and carbon materials as the CE materials of DSSCs to increase the electrical conductivity and number of exposed active sites at the surface [66-69,98]. Therefore, NiS was fabricated by the simple hydrothermal method, and subsequently mixed with conductive carbon $(\mathrm{Cc})$ to utilize the composite $(\mathrm{NiS} / \mathrm{Cc}$ ) as the $\mathrm{CE}$ of DSSCs [67]. The addition of Cc lowered the impedance at the electrode/electrolyte interface and enhanced the electrocatalytic activity of the hybrid. Thus, the cell with NiS/Cc CE $(8.15 \%)$ yielded a higher PCE than a cell with pure NiS CE (6.04\%), which is comparable to that of a device with platinum CE (8.29\%). Wang's group [98] successfully used the simple hydrothermal approach to fabricate $\mathrm{NiS}_{2}$ nanoparticles with RGO (NiS $@$ @GO). The resultant products revealed superior electrocatalytic performance toward triiodide reduction, owing to the synergetic effect between the excellent conductivity of RGO and the outstanding catalytic activity of $\mathrm{NiS}_{2}$. Notably, the DSSC with NiS2@RGO CE exhibited a higher PCE (8.55\%) than the cell with platinum CE (8.15\%). Subsequently, Chakraborty et al. [69] designed NiS nanoparticles that were grown on rGO (NiS/rGO). The addition of rGO provided abundant charge-transfer channels and improved the electrocatalytic activity for triiodide reduction. The PCE of the DSSC based on $\mathrm{NiS} / \mathrm{rGO}$ CE reached 9.5\%, which was higher than the values currently found in the literature for DSSCs employing nickel sulfides as the CEs.

Our group [15] subsequently synthesized Nio.85Se microspheres on RGO ( $\mathrm{Ni}_{0.85} \mathrm{Se} @ \mathrm{RGO}$ ) and employed them as the CE of DSSCs (Fig. 3a). The $\mathrm{Ni}_{0.85}$ Se@RGO displayed outstanding conductivity and catalytic activity owing to its nonstoichiometric composition and porous architecture. The DSSC based on the $\mathrm{Ni}_{0.85} \mathrm{Se} @$ RGO CE yielded a higher PCE (7.82\%) than a cell based on platinum CE (7.54\%). As seen in Fig. 3b, our group [25] first developed hollow and hybrid $\mathrm{NiSe}-\mathrm{Ni}_{3} \mathrm{Se}_{2}$ to optimize their unique valence electronic configurations and unsaturated selenium atoms. Benefiting from the hollow and hybrid architecture, $\mathrm{NiSe}-\mathrm{Ni}_{3} \mathrm{Se}_{2} / \mathrm{RGO}$ nanomaterials revealed outstanding electron conduction and electrocatalytic properties. As the CE

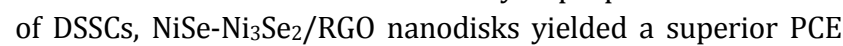
(7.87\%), outperforming a cell employing platinum (7.28\%). The novel research provided a new strategy to engineer electrocatalysts with low charge transfer resistances and high electrocatalytic activity. In addition, Wu's group [99] fabricated $\mathrm{Ni}_{0.85} \mathrm{Se}$ nanosheets that were grown on $\mathrm{rGO}\left(\mathrm{Ni}_{0.85} \mathrm{Se} / \mathrm{rGO}\right)$ with various concentrations via the simple hydrothermal technique. Based on the optimal rGO concentration, the efficiency of the cell with $\mathrm{Ni}_{0.85} \mathrm{Se} / \mathrm{rGO}$ CE reached $9.75 \%$, which was increase of $19.6 \%$, compared with that of a cell utilizing platinum CE (8.15\%).

\subsection{Doping of external elements into nickel-based compounds}

To improve the electrocatalytic activity of nickel oxide, a porous sulfur-doped nickel oxide (S-NiO) was engineered on FTO by Li and coworkers [70] via electrophoretic deposition. The sulfur dopant in the NiO could tremendously enhance the charge transfer rate and surface area of the electrochemical reaction. With optimal dopant, the DSSC based on S-NiO CE (5.04\%) yielded a significantly higher PCE than that based on pure NiO CE $(0.31 \%)$. However, the efficiency of S-NiO was still lower than that of platinum (6.08\%). The composite of $\mathrm{Ni}_{3} \mathrm{~S}_{2} / \mathrm{Ni}-\mathrm{P}$ coated on polyimide (PI) substrate was applied by Lin et al. [71] as a FTO-free CE, in which the Ni-P layer at the bottom served as the conductive layer, instead of the common transparent conducting oxide, and the $\mathrm{Ni}_{3} \mathrm{~S}_{2}$ layer above acted as the electrocatalyst for the reduction of triiodide. As a result, the cell based on $\mathrm{Ni}_{3} \mathrm{~S}_{2}$ /Ni-P-coated PI CE realized a great PCE of $6.28 \%$, which was superior to that a cell based on platinum-coated ITO CE (6.17\%). The NiS/ $\mathrm{Ni}_{3} \mathrm{~S}_{2}$ hybrid grown on a nickel foil was directly synthesized by Pan's group [74] to function as a FTO-free CE in DSSCs. They indicated that the addition of hydrazine was the crucial reason for the formation of 
(a)
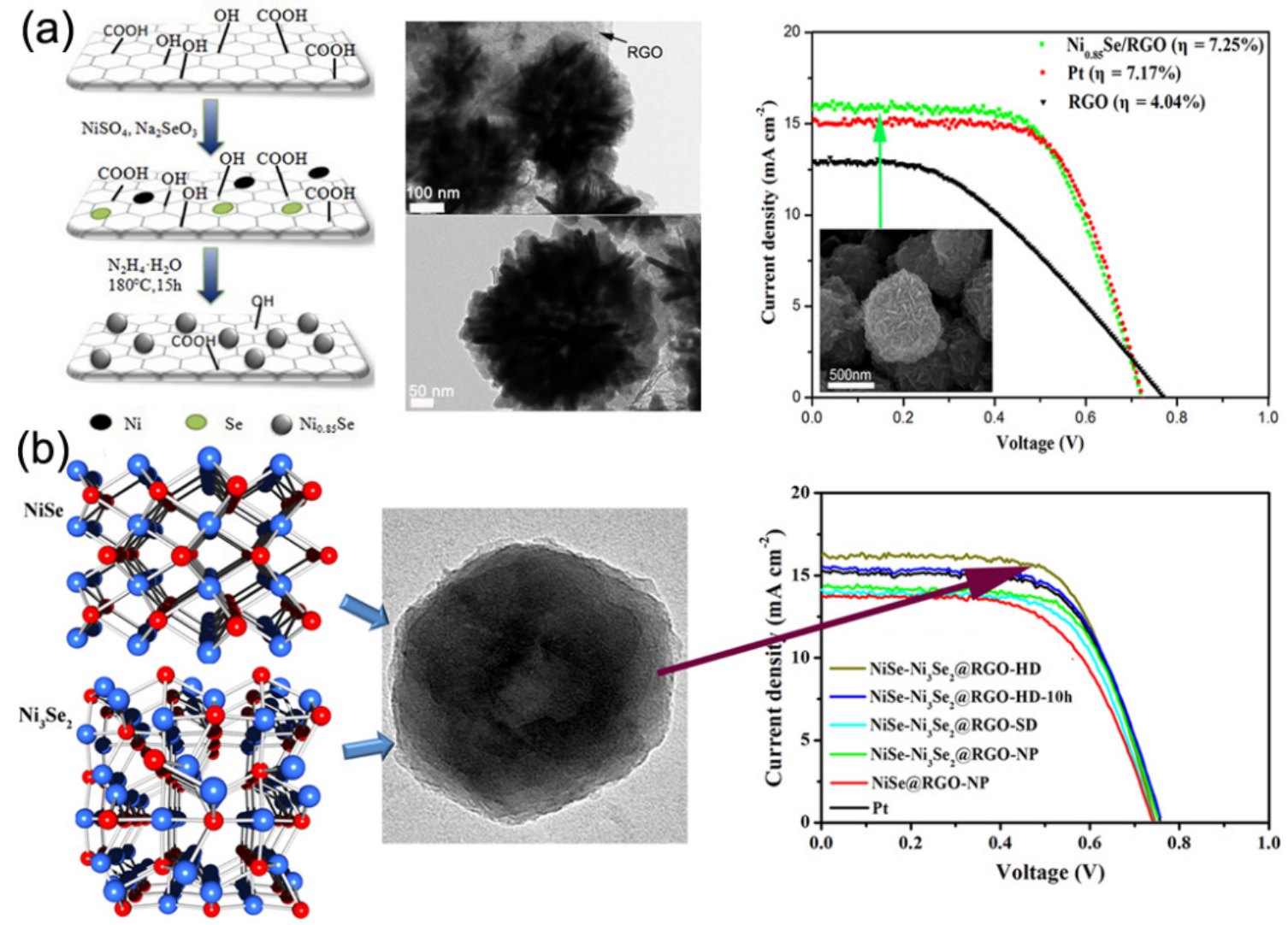

Fig. 3. (a) Formation process and TEM images of mesoporous $\mathrm{Ni}_{0.85} \mathrm{Se} / \mathrm{RGO}$ nanospheres, and photocurrent density-voltage plots of the DSSCs based on $\mathrm{Ni}_{0.85} \mathrm{Se} / \mathrm{RGO}$, platinum, and RGO CEs. Reproduced from ref. [15]. (b) TEM image of $\mathrm{NiSe}-\mathrm{Ni}_{3} \mathrm{Se}_{2} / \mathrm{RGO}$ nanodisks, and photocurrent density-voltage curves of DSSCs with NiSe- $\mathrm{Ni}_{3} \mathrm{Se}_{2} / \mathrm{RGO}$ series and platinum CEs. Reproduced from ref. [25].

$\mathrm{NiS} / \mathrm{Ni}_{3} \mathrm{~S}_{2}$, which resulted from the formation of sufficient $\mathrm{S}^{2-}$. The $\mathrm{NiS} / \mathrm{Ni}_{3} \mathrm{~S}_{2}$ hybrid exhibited superior conductivity and catalytic activity, compared to those of $\mathrm{Ni}_{3} \mathrm{~S}_{2}$. The DSSC with $\mathrm{NiS} / \mathrm{Ni}_{3} \mathrm{~S}_{2} \mathrm{CE}$ exhibited a PCE of $7.20 \%$, which was comparable to that of a cell employing platinum CE (7.56\%). In addition to these, nickel-selenium compounds have also attracted much attention owing to their superior electrochemical properties, compared to the pure phase. Chen and coworkers [100] designed and fabricated $\mathrm{Ni}_{\chi} \mathrm{S}_{\gamma} / \mathrm{NiSe}_{2}$ nanohybrid on FTO. Electrochemical measurements revealed that $\mathrm{Ni}_{x} \mathrm{~S}_{\gamma} / \mathrm{NiSe}_{2}$ showed preeminent electrocatalytic activity toward triiodide reduction, compared with those of pure $\mathrm{Ni}_{\chi} \mathrm{S}_{\gamma}$ and $\mathrm{NiSe}_{2}$, because of the synergetic effects of the various constituents. Notably, the PCE of the DSSC based on $\mathrm{Ni}_{\chi} \mathrm{S}_{\gamma} / \mathrm{NiSe}_{2}$ CE reached $8.64 \%$, which was superior to those of cells based on $\mathrm{Ni}_{\chi} \mathrm{S}_{\gamma}(7.95 \%)$ and $\mathrm{NiSe}_{2}$ (7.47\%).

\section{Monometallic iron-based compounds}

As a common transition metal, iron is one of the most abundant elements in the natural environment. Iron compounds exhibit various compositions, valence states, and crystal architectures. In the last few years, iron compounds, including oxides, sulfides, and selenides, have been extensively developed as CEs in DSSCs owing to their unique electrical, optical, and photovoltaic properties.

\subsection{Pure iron-based compounds}

Based on first-principle calculations, Hou and colleagues [26] investigated the electrocatalytic activity of $\alpha-\mathrm{Fe}_{2} \mathrm{O}_{3}$ nanocrystals, which served as the CEs of DSSCs, through theoretical prediction and experimental validation (Fig. 4). Electrochemical and photovoltaic measurements confirmed that $\alpha-\mathrm{Fe}_{2} \mathrm{O}_{3}$ exhibited high conductivity and excellent electrocatalytic activity for the reduction of triiodide. The DSSC with $\alpha-\mathrm{Fe}_{2} \mathrm{O}_{3} \mathrm{CE}$ revealed an efficiency of $6.96 \%$, which was slightly lower than that of a cell using platinum CE (7.32\%). Subsequently, flower-like $\mathrm{Fe}_{3} \mathrm{O}_{4}$ was synthesized by Shi's group [76]. By controlling the annealing temperature, the as-designed $\mathrm{Fe}_{3} \mathrm{O}_{4}$ was transformed into $\alpha-\mathrm{Fe}_{2} \mathrm{O}_{3}$ or $\gamma-\mathrm{Fe}_{2} \mathrm{O}_{3}$, which was used as CEs in DSSCs. It was observed that hierarchical $\mathrm{Fe}_{3} \mathrm{O}_{4}$ exhibited the best electron conduction and electrocatalytic activity among the iron-based compounds. With $\mathrm{Fe}_{3} \mathrm{O}_{4} \mathrm{CE}$, a PCE of $7.65 \%$ was obtained, which was comparable to that of a device with platinum CE (7.87\%).

Iron pyrite $\left(\mathrm{FeS}_{2}\right)$ is a potential photovoltaic material by virtue of its high photoadsorption parameter, narrow bandgap, minimal toxicity, and low cost [22]. Ever since Zhang and his coworkers [101] examined the possibility of utilizing $\mathrm{FeS}_{2}$ as the CE of DSSCs, researchers have paid attention to its application in this field. As a result, $\mathrm{FeS}_{2}$ nanocrystal ink was prepared 

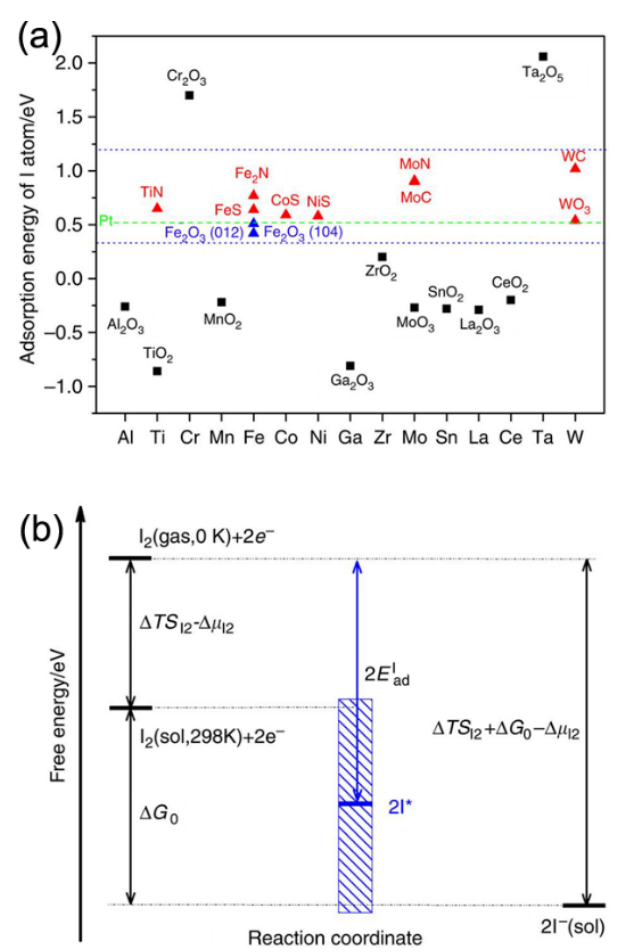

Fig. 4. (a) Adsorption energies of I atom on various compounds and frameworks in the gas phase or in $\mathrm{CH}_{3} \mathrm{CN}$ solvent calculated through DFT method. The red triangles correspond to the active materials reported; the blank squares indicate the unreported materials, which were estimated to be less catalytically active. (b) Demonstration of range estimation model for suitable electrodes on the basis of the adsorption energy of I atom. Reproduced from ref. [26].

by Wang et al. [22] via a solution method. Through electrochemical measurements, the as-synthesized $\mathrm{FeS}_{2}$ ink revealed remarkable electrocatalytic activity and outstanding stability in the process of reducing triiodide to iodide in the electrolyte. They further demonstrated that low-cost $\mathrm{FeS}_{2}$ offered the possibility of replacing the expensive platinum as the CE material of DSSCs. Though the device composed of $\mathrm{FeS}_{2}$ ink revealed a promising PCE of $7.31 \%$, this was still lower than that of the cell with platinum CE (7.52\%). Hence, spray pyrolysis method was utilized by Xiong and his colleagues [102] to deposit $\mathrm{FeS}_{2}$ on FTO. Different CE materials are suitable for different redox couples in electrolytes. The as-prepared $\mathrm{FeS}_{2}$ film displayed excellent electrocatalytic activity, comparable to those of PEDOT in $\mathrm{Co}(\mathrm{III}) / \mathrm{Co}(\mathrm{II})$ and platinum in $\mathrm{I}_{3}^{-} / \mathrm{I}^{-}$electrolytes, which resulted in great optical reflectivity, which in turn boosted the optical dispersion in DSSCs. Ultimately, the PCE of a DSSC based on the $\mathrm{FeS}_{2} \mathrm{CE}$ reached $7.97 \%$, whereas that of a

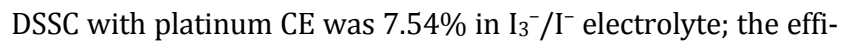
ciency of the $\mathrm{FeS}_{2} \mathrm{CE}(6.34 \%)$ was similar to that of the PEDOT CE (6.31\%) in Co(III)/Co(II) electrolyte. The good properties of the $\mathrm{FeS}_{2} \mathrm{CE}$ in various electrolytes suggested that this material was a promising alternative among the multitudinous CE materials.

In recent years, much effort has been devoted to the application of iron selenides in the development of DSSCs owing to their unusual electrochemical properties and high stability in $\mathrm{I}_{3}{ }^{-} / \mathrm{I}^{-}$electrolyte $[23,78-81,103]$. Three-dimensional flow- er-like $\mathrm{FeSe}_{2}$ films were engineered for the first time by Wang's group [79] that functioned as CEs of DSSCs. Low charge transfer resistance and high catalytic activity were revealed for the as-prepared $\mathrm{FeSe}_{2}$ through electrochemical tests, which outperformed the conventional platinum. It is noteworthy that the efficiency of the 3D flower-like $\mathrm{FeSe}_{2} \mathrm{CE}$ reached $8.00 \%$, which was even superior to that of the DSSC with platinum CE (7.87\%). The architectures of catalysts could effectively influence the performance and stability of these materials. Hence, Qian and coworkers [80] fabricated and investigated various $\mathrm{FeSe}_{2}$ with different morphologies as CEs in DSSCs. Through comparison, they found that 3D FeSe2 microspheres composed of hierarchical nanosheets ( $\mathrm{FeSe}_{2} \mathrm{NSs}$ ) displayed the highest conductivity and electrocatalytic activity for $\mathrm{I}_{3}{ }^{-}$reduction among the various $\mathrm{FeSe}_{2}$ synthesized. The DSSC based on $\mathrm{FeSe}_{2}$ NS CE exhibited a satisfactory PCE (8.39\%) that surpassed that of a cell with platinum CE (8.20\%). The excellent electron conduction, remarkable electrocatalytic activity, and high photoelectric conversion efficiency indicate that $\mathrm{FeSe}_{2}$ materials are a potential alternative option to the precious platinum as the CE of DSSCs.

\subsection{Composites of pure iron-based compounds and carbon materials}

To further improve the efficiency and corrosion resistance of $\mathrm{Fe}_{3} \mathrm{O}_{4}$, Shi's group [82] obtained the composite of $\mathrm{Fe}_{3} \mathrm{O}_{4}$ and rosin carbon by an annealing process for use as the $\mathrm{CE}$ of DSSCs; this composite revealed excellent electrocatalytic performance. It was notable that the DSSC fabricated with the as-constructed CE yielded a PCE of 8.11\%. In addition, Yao et al. [28] studied flower-like mesoporous $\mathrm{Fe}_{3} \mathrm{O}_{4}$ wrapped in nitrogen-doped graphene ( $\mathrm{Fe}_{3} \mathrm{O}_{4} \mathrm{UFM} @ N-\mathrm{RGO}$; Fig. $5 \mathrm{a}$ and $\left.5 \mathrm{~b}\right)$. The addition of N-RGO could not only provide more catalytically active sites, but also accelerate the charge transfer in $\mathrm{Fe}_{3} \mathrm{O}_{4} \mathrm{UFM} @ \mathrm{~N}-\mathrm{RGO}$. As seen in Fig. 5c and 5d, a better efficiency was obtained for the DSSC with $\mathrm{Fe}_{3} \mathrm{O}_{4} \mathrm{UFM} @ N-R G O$ CE (9.26\%) than for the DSSC with $\mathrm{Fe}_{3} \mathrm{O}_{4} \mathrm{UFM}(8.16 \%), \mathrm{Fe}_{3} \mathrm{O}_{4} \mathrm{UFM} @$ RGO (8.64\%), or platinum (7.72\%) CE. Following that, multifunctional nanocomposites were engineered and researched as CEs of DSSCs by the group by wrapping $\mathrm{Fe}_{3} \mathrm{O}_{4}$ nanoparticles anchored on hollow carbon microspheres with nitrogen-doped graphene (HCCMS/ $\mathrm{Fe}_{3} \mathrm{O}_{4} @ \mathrm{~N}-\mathrm{RGO}$ ) [27]. Owing to triple synergistic interactions, $\mathrm{HCCMS} / \mathrm{Fe}_{3} \mathrm{O}_{4} @ \mathrm{~N}-\mathrm{RGO}$ presented conductivity, electrocatalytic activity, and corrosion stability in the electrolyte that were superior to those of platinum. Notably, the cell with $\mathrm{HCCMS} / \mathrm{Fe}_{3} \mathrm{O}_{4} @ \mathrm{~N}-\mathrm{RGO} \mathrm{CE}$ showed an outstanding PCE of $9.89 \%$, which was $28.78 \%$ higher than that of the cell with platinum CE $(7.68 \%)$. This novel study opened up the possibility of preparing multifunctional carbon-based nanohybrids exhibiting high performances and broadened the potential applications of $\mathrm{Fe}_{3} \mathrm{O}_{4}$ in DSSCs.

By combining $\mathrm{FeS}_{2}$ with highly conductive materials such as graphene, it is hoped that highly electrocatalytic materials for DSSCs can be assembled. Shapter et al. [104] reported the synthesis of the nanocomposite of sphere-type $\mathrm{FeS}_{2}$ and sulfur-doped graphene $\left(\mathrm{SGN}_{\mathrm{F}} \mathrm{FeS}_{2}\right)$. The results of electrochemical 

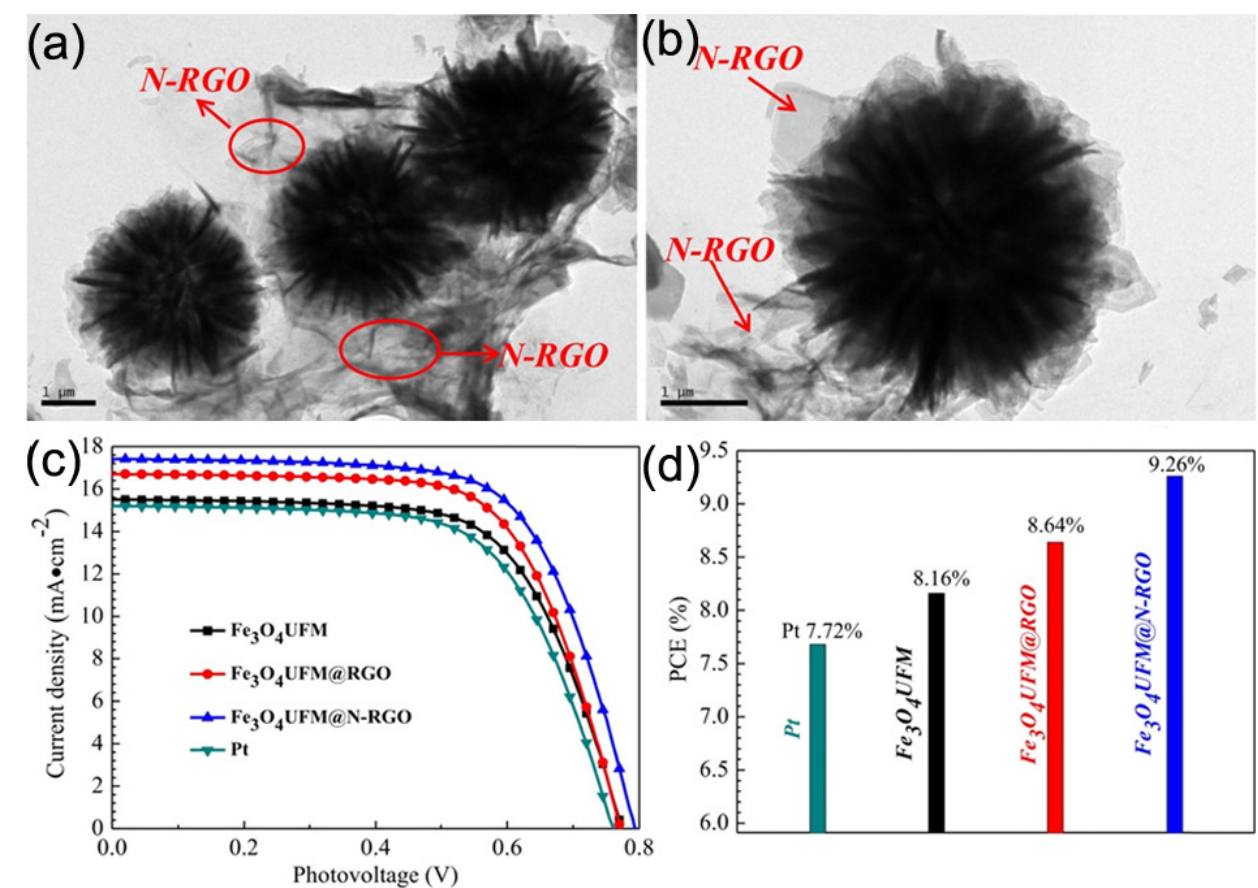

Fig. 5. (a, b) TEM images of $\mathrm{Fe}_{3} \mathrm{O}_{4} \mathrm{UFM} @ N-R G O ;(c)$ Photocurrent density-voltage plots of DSSCs with different CEs; (d) PCEs of all the samples and platinum. Reproduced from ref. [28].

measurements indicated that the addition of SGN greatly improved the conductivity of the product. Benefiting from the synergetic effect between $\mathrm{SGN}$ and $\mathrm{FeS}_{2}$, the SGN-FeS2-based DSSC yielded a PCE of $8.1 \%$, apart from displaying remarkable durability.

\subsection{Doping of external elements into iron-based compounds}

Sulfur-rich iron sulfides exhibit semiconducting properties, which lead to a high charge transfer impedance that hinders the reduction of triiodide in the electrolyte. As a consequence, adjusting the architectural feature and $\mathrm{Fe} / \mathrm{S}$ ratio is a promising strategy to enhance the electrocatalytic activity of iron sulfides, which act as the CEs in DSSCs [105]. Moreover, there are reports that iron carbide encapsulated in carbon material could activate the abundant active sites of carbon shells and regulate their electronic conduction [106]. Therefore, Chen and his colleagues applied the one-pot carbonization-sulfurization method to design a novel nanocomposite of $\mathrm{Fe}_{1-\chi} \mathrm{S}$ incorporated in $\mathrm{Fe}_{3} \mathrm{C}$-encapsulated and nitrogen-doped carbon nanotubes ( $\left.\mathrm{Fe}_{1-\chi} \mathrm{S} / \mathrm{Fe}_{3} \mathrm{C}-\mathrm{NCNTs}\right)$. The unique architecture and composition of $\mathrm{Fe}_{1-\chi} \mathrm{S} / \mathrm{Fe}_{3} \mathrm{C}-\mathrm{NCNTs}$ greatly improved the electrical conductivity and electrocatalytic activity on account of the synergetic effects of $\mathrm{Fe}_{3} \mathrm{C}$ - as well as N-CNTs, and provided electron transport pathways and $\mathrm{Fe}_{1-\chi} \mathrm{S}$, which was rich in vacancies. The DSSC with the $\mathrm{Fe}_{1-\chi} \mathrm{S} / \mathrm{Fe}_{3} \mathrm{C}$-NCNT CE displayed a higher PCE (8.67\%) than the cells with $\mathrm{Fe}_{3} \mathrm{C}-\mathrm{NCNT}$ (6.49\%), $\mathrm{Fe}_{1-\chi} \mathrm{S}$ (7.84\%), and platinum $(7.75 \%) \mathrm{CEs}$, and exhibited remarkable stability after long-term illumination. However, there are still few iron-based polybasic hybrids that are utilized as CEs in DSSCs. Therefore, these materials would become a research hotspot in the future.

\section{Cobalt-, nickel-, and iron-based bimetal alloys and compounds}

Up to now, various CE materials (such as carbon materials, conductive polymers, and metal alloys and compounds) offer promise as alternatives to platinum. Among them, transition metal compounds (TMCs) are regarded as the most eye-catching CE materials owing to the similarity in their electronic structures with that of platinum. Moreover, TMCs that originally display good durability and excellent thermal and electrical conductivities reveal outstanding electrochemical activity as electrocatalysts. Bimetal transition metal alloys and compounds such as $\mathrm{MIn}_{2} \mathrm{~S}_{4}(\mathrm{M}=\mathrm{Fe}, \mathrm{Co}, \mathrm{Ni}), \mathrm{NiCo}_{2} \mathrm{~S}_{4}, \mathrm{CoFeS}_{2}$, and $(\mathrm{Ni}, \mathrm{Fe}) \mathrm{S}_{2}$ have been successfully applied as CEs in DSSCs, and these exhibited high performances owing to the unique coexistence of two different cations in a single crystal structure [107]. A number of photovoltaic parameters are listed in Table 2.

\subsection{Cobalt- and nickel-based alloys and compounds}

Among the bimetal TMCs, $\mathrm{NiCo}_{2} \mathrm{O}_{4}$ shows admirable electrochemical characteristics owing to its outstanding electron conduction and stability. Notably, it has been revealed that $\mathrm{NiCo}_{2} \mathrm{O}_{4}$ exhibits a more abundant redox reaction and higher electroconductivity and electrocatalytic activity than pure cobalt or nickel oxides. However, the application of $\mathrm{NiCo}_{2} \mathrm{O}_{4}$ materials as CEs in DSSCs is limited. Shi et al. [108] first utilized $\mathrm{NiCo}_{2} \mathrm{O}_{4}$ as the CE in DSSCs. However, the possibilities of high corrosion and interaction of the $\mathrm{NiCo}_{2} \mathrm{O}_{4} \mathrm{CE}$ in the electrolyte led to a poor PCE of $0.78 \%$. To overcome this issue, Li's group 
Table 2

Photovoltaic parameters of DSSCs based on cobalt-, nickel-, and iron-based multi-metal alloy and compound CEs.

\begin{tabular}{|c|c|c|c|c|c|c|}
\hline CE material & $\begin{array}{c}J_{\mathrm{sc}}(\mathrm{mA} \\
\left.\mathrm{cm}^{-2}\right)\end{array}$ & $\begin{array}{l}V_{\text {oc }} \\
\text { (V) }\end{array}$ & $\mathrm{FF}$ & $\begin{array}{l}\text { PCE } \\
(\%)\end{array}$ & $\begin{array}{l}R_{\mathrm{ct}} \\
(\Omega)\end{array}$ & Ref. \\
\hline $\mathrm{NiCO}_{2} \mathrm{O}_{4}$ & 16.58 & 0.68 & 0.63 & 7.09 & 3.13 & {$[110]$} \\
\hline $\mathrm{NiCo}_{2} \mathrm{O}_{4} @ \mathrm{RGO}$ & 14.92 & 0.69 & 0.60 & 6.17 & 0.27 & {$[32]$} \\
\hline $\mathrm{NiCO}_{2} \mathrm{O}_{4} /$ carbon black & 16.08 & 0.65 & 0.60 & 6.27 & 2.20 & {$[126]$} \\
\hline $\mathrm{NiCo}_{2} \mathrm{~S}_{4}$ & 14.11 & 0.72 & 0.60 & 6.14 & 2.40 & [113] \\
\hline $\mathrm{CoNi}_{2} \mathrm{~S}_{4}$ nanoribbons & 15.3 & 0.68 & 0.68 & 7.03 & 5.10 & [117] \\
\hline $\mathrm{NiCo}_{2} \mathrm{~S}_{4}$ & 13.6 & 0.758 & 0.68 & 7.03 & 3.90 & {$[127]$} \\
\hline $\mathrm{NiCo}_{2} \mathrm{~S}_{4}$ nanoparticles & 17.17 & 0.747 & 0.69 & 8.94 & 1.58 & {$[128]$} \\
\hline $\mathrm{NiCo}_{2} \mathrm{~S}_{4} \mathrm{BHSs}$ & 17.4 & 0.84 & 0.65 & 9.49 & 2.48 & [116] \\
\hline $\mathrm{NiCo}_{2} \mathrm{~S}_{4} / \mathrm{NiS}$ microspheres & 17.7 & 0.74 & 0.67 & 8.8 & 2.20 & [129] \\
\hline $\mathrm{NiCoS} / \mathrm{rGO}-2 \%$ & 16.11 & 0.77 & 0.72 & 8.96 & 2.79 & [114] \\
\hline $\mathrm{NiS}_{2} / \mathrm{CoS}_{2}$ & 17.45 & 0.72 & 0.65 & 8.22 & 0.28 & [130] \\
\hline $\begin{array}{l}\mathrm{Ni}_{0.33} \mathrm{Co}_{0.67} \mathrm{Se} \text { micro- } \\
\text { spheres }\end{array}$ & 17.29 & 0.79 & 0.67 & 9.01 & 1.11 & {$[30]$} \\
\hline $\begin{array}{l}\text { Ni-Co-Se hollow micro- } \\
\text { spheres }\end{array}$ & 17.78 & 0.77 & 0.66 & 9.04 & 1.27 & {$[120]$} \\
\hline $\mathrm{FeCo}_{2}$ nanofiber alloys & 12.09 & 0.71 & 0.59 & 5.06 & 40.69 & [131] \\
\hline $\mathrm{CoFe}_{2} \mathrm{O}_{4} @ \mathrm{CNTs} / \mathrm{PPy}$ & 13.40 & 0.71 & 0.69 & 6.55 & 2.29 & {$[132]$} \\
\hline $\mathrm{CoFeS}_{2} / \mathrm{rGO}$ & 15.85 & 0.78 & 0.71 & 8.82 & 1.24 & [133] \\
\hline Co-Fe-S & 17.5 & 0.79 & 0.66 & 9.06 & 2.73 & \multirow{2}{*}{ [31] } \\
\hline Co-Fe-Se & 18.4 & 0.76 & 0.69 & 9.58 & 1.10 & \\
\hline $\operatorname{Pod}(\mathrm{N})-\mathrm{FeNi}$ & 16.16 & 0.75 & 0.73 & 8.82 & 0.54 & [134] \\
\hline $\mathrm{Fe}_{0.7} \mathrm{Ni}_{0.3} / \mathrm{RGO}$ & 10.37 & 0.66 & 0.64 & 4.11 & 0.17 & [135] \\
\hline $\mathrm{Ni}_{0.5} \mathrm{Fe}_{0.5} \mathrm{~S}_{2} / \mathrm{C}$ & 15.83 & 0.65 & 0.66 & 6.79 & 0.88 & [136] \\
\hline
\end{tabular}

[32] introduced RGO during the synthesis of $\mathrm{NiCo}_{2} \mathrm{O}_{4}$ nanobelts, thus effectively avoiding their aggregation and lowering the electron transfer resistance. Though the as-fabricated $\mathrm{Ni}$ $\mathrm{Co}_{2} \mathrm{O}_{4} / \mathrm{RGO}$ CE yielded a slightly higher PCE than the platinum CE $(6.07 \%)$, the efficiency only reached $6.17 \%$. Considering the fact that the morphology of the catalyst greatly impacts the conversion efficiency [109], Zhang and coworkers [110] synthesized nanotube-type and honeycomb-like $\mathrm{NiCo}_{2} \mathrm{O}_{4}$ with mesoporous structures by electrospinning method. It was worth noting that the honeycomb-like $\mathrm{NiCo}_{2} \mathrm{O}_{4}$ revealed lower electron resistance and higher electrocatalytic activity than $\mathrm{NiCo}_{2} \mathrm{O}_{4}$ nanotubes, which were comparable to those of platinum. As a result, the DSSC based on honeycomb-like $\mathrm{NiCo}_{2} \mathrm{O}_{4}$ CE displayed a PCE of 7.09\%, which slightly surpassed that of the cell employing platinum CE (7.05\%). Besides, this DSSC exhibited superior durability, compared to that of platinum, owing to its unique 3D network structure. In order to further explore the unique architecture and fabricate more open electron as well as ion channels, a series of $\mathrm{NiCo}_{2} \mathrm{O}_{4}$ nanomaterials with different morphologies were engineered by $\mathrm{Du}$ and colleagues [111] via the facile hydrothermal approach, which was followed by thermal treatment. The 3D nanoflowers showed the best electroconductivity and electrocatalytic activity, compared with those of the other nanomaterials (nanosheets and nanorods). Consequently, they also revealed the highest efficiency of $8.48 \%$, and even outperformed platinum (8.11\%) by benefiting from their porous structure and 3D construction.

With the typical spinel structure, ternary $\mathrm{NiCo}_{2} \mathrm{~S}_{4}$ reveals more redox reactions, valence interchange, and charge hopping, compared to those of single cobalt or nickel sulfides, owing to the coexistence of cobalt and nickel with different valencies [112]. Therefore, numerous efforts have been made to investigate the electrocatalytic properties of $\mathrm{NiCo}_{2} \mathrm{~S}_{4}$ as CEs in DSSCs that exhibit excellent electroconductivity and electrocatalytic activity. Lin's group [113] for the first time assembled $\mathrm{NiCo}_{2} \mathrm{~S}_{4}$, which was grown on FTO, and studied its application as a platinum-free CE of DSSCs. They were convinced that the as-synthesized $\mathrm{NiCo}_{2} \mathrm{~S}_{4}$ could exhibit a remarkable catalytic activity towards triiodide reduction. By using the $\mathrm{NiCo}_{2} \mathrm{~S}_{4} \mathrm{CE}$, the DSSC yielded a PCE of $6.14 \%$, which approached that of a cell utilizing platinum CE (6.29\%). This research showed that $\mathrm{NiCo}_{2} \mathrm{~S}_{4}$ might be a promising substitute for platinum as a CE material. Addition of carbonaceous materials is one of the most effective methods to improve the electrocatalytic activity of CE materials and accelerate the electron transfer process for triiodide reduction. Furthermore, Lu and fellow workers [114] mixed nickel cobalt sulfide with rGO (NCS/rGO), and applied it as the CE in DSSCs. It was observed that rGO could not only speed up $\mathrm{I}_{3}^{-}$reduction by functioning as a cocatalyst, but also reduce the series resistance by acting as a promotor of the conductivity. Subsequently, they proved that the series resistance slightly influenced the catalytic activity of the CE. Therefore, the improvements in the electrochemical and photovoltaic properties were mostly attributed to the cocatalyzing function of rGO in the as-engineered NCS/rGO. The efficiency of NCS/rGO reached $8.96 \%$, which was slightly lower than that of platinum (9.11\%). $\mathrm{NiCo}_{2} \mathrm{~S}_{4}$ nanoribbons and nanorods grown on carbon fibers were studied and applied as CEs in DSSCs by Murugan et al. [115]. Fig. 5a-5d show that the electrocatalytic properties of CEs for DSSCs are not only related to the inherent characteristics of the CE materials, but also affected by their architectures. As a consequence, $\mathrm{NiCo}_{2} \mathrm{~S}_{4}$ nanomaterials with three different morphologies, including $\mathrm{NiCo}_{2} \mathrm{~S}_{4}$ nanoparticles ( $\mathrm{NiCo}_{2} \mathrm{~S}_{4} \mathrm{NPs}$ ), $\mathrm{NiCo}_{2} \mathrm{~S}_{4}$ solid spheres ( $\mathrm{NiCo}_{2} \mathrm{~S}_{4} \mathrm{SSs}$ ), and $\mathrm{NiCo}_{2} \mathrm{~S}_{4}$ double-shelled ball-in-ball hollow spheres ( $\mathrm{NiCo}_{2} \mathrm{~S}_{4} \mathrm{BHSs}$ ), were designed by Qian and coworkers [116] through a two-pot solvothermal approach by using various solvents. As exhibited in Fig. 5e, $\mathrm{NiCo}_{2} \mathrm{~S}_{4}$ BHSs reveal excellent catalytic activity for photovoltaics and for the hydrogen evolution reaction. By comparing the electrochemical properties of these $\mathrm{NiCo}_{2} \mathrm{~S}_{4}$ nanomaterials, the effect of architecture was examined. Without any exception, $\mathrm{NiCo}_{2} \mathrm{~S}_{4}$ BHS exhibited the lowest electrical resistance and highest electrocatalytic activity, compared with those of the other two $\mathrm{NiCo}_{2} \mathrm{~S}_{4}$, and these properties even surpassed those of platinum. It is worth mentioning that the DSSC based on $\mathrm{NiCo}_{2} \mathrm{~S}_{4}$ BHS CE revealed a higher PCE (9.49\%) than the DSSCs with $\mathrm{NiCo}_{2} \mathrm{~S}_{4} \mathrm{NP}$ (7.46\%), $\mathrm{NiCo}_{2} \mathrm{~S}_{4} \mathrm{SS}$ (7.58\%), and platinum (8.30\%) CEs. This experiment verified that it was feasible to improve the electrochemical performance by improving the morphology of the catalyst.

In view of their higher electroconductivity, bimetal selenides would be more advantageous than the corresponding binary selenides, as they profit from the copresence of nickel and cobalt [118]. It is generally known that the morphology and stoichiometric ratio play decisive roles in determining the elec- 
trocatalytic activity of CE materials [24]. Wang and coworkers [119] engineered ternary nickel cobalt selenide $\left(\mathrm{Ni}_{\chi} \mathrm{Co}_{\gamma} \mathrm{Se}\right)$ nanoparticles with different $\mathrm{Ni} / \mathrm{Co}$ molar ratios by directly depositing them on FTO. By comparing the electrochemical performances, the resultant ternary $\mathrm{Ni}_{\chi} \mathrm{Co}_{\gamma} \mathrm{Se}$ was found to display lower charge transfer impedance and higher catalytic activity than pure CoSe and NiSe. The results of photovoltaic measurements revealed that $\mathrm{Ni}_{0.12} \mathrm{Co}_{0.80}$ Se realized the highest efficiency $(8.61 \%)$ among all the materials, which exceeded that of platinum (7.82\%). Moreover, Qian et al. [30] fabricated the ternary $\mathrm{Ni}_{\chi} \mathrm{Co}_{1-\chi} \mathrm{Se}$ nanohybrid through a two-step solvothermal method. By controlling the Ni/Co molar ratio, the morphologies of ternary $\mathrm{Ni}_{x} \mathrm{Co}_{1-x} \mathrm{Se}$ could be easily modulated, which affected their electrochemical properties. Based on the unique structure and controllable composition, the as-fabricated $\mathrm{Ni}_{\chi} \mathrm{Co}_{1-\chi} \mathrm{Se}$ exhibited high electroconductivity and catalytic activity. Electrochemical and photovoltaic tests showed that 3D dandelion-like $\mathrm{Ni} 0.33 \mathrm{Co}$ 0.67Se microspheres exhibited the highest electrocatalytic activity and PCE (9.01\%), outperforming even platinum (PCE of $8.30 \%$ ). To further investigate the effect of stoichiometric ratio on the electrocatalytic activity of CE materials, this research group [120] subsequently designed four hollow $\mathrm{Ni}$-Co-Se microspheres with different nickel and cobalt contents by adjusting the reaction temperature between 140 and $200{ }^{\circ} \mathrm{C}$. They revealed that increasing the temperature would increase both the nickel and cobalt contents as a result of the increase in the resultant $\mathrm{Se}^{2-}$. A series of electrochemical measurements indicated that Ni-Co-Se-180 (Ni : $\mathrm{Co}: \mathrm{Se}=0.28$ : $0.40: 2$ ) exhibited the lowest electron transfer impedance and highest current density. It was expected that the DSSC with Ni-Co-Se-180 CE showed the highest efficiency of 9.04\% among the four Ni-Co-Se alloys, which represents an improvement of $12.01 \%$, compared with that of a cell with platinum CE $(8.07 \%)$. This work not only proved that Ni-Co-Se compounds could be applied as an alternative to platinum as the CE material in DSSCs, but also provided a new pathway to synthesize platinum-free composites.

Although many efforts have been made to explore platinum-free CE materials, their non-ideal electron transfer performances have resulted in poor long-term stabilities [121]. As a promising solution, alloy materials of transition metals have received much attention owing to their superior electrical conductivity and electrocatalytic activity, compared to those of single metals [122]. To reduce the production cost and promote the large-scale application of DSSCs, vast efforts have been made to exploit platinum-free alloys as CE materials with excellent properties. As a consequence, a mild hydrothermal method was reported by Chen et al. [123], who prepared binary Co-Ni alloys with various nickel amounts, along with single cobalt and nickel, on FTO. The results of many measurements demonstrated that the as-fabricated Co-Ni alloys achieved much faster electron transfer and exhibited better electrocatalysis than pure cobalt and nickel, among which $\mathrm{CoNi}_{0.25}$ alloy was the best. As expected, CoNio.25 yielded the highest PCE of $8.39 \%$, which significantly surpassed that of platinum (6.96\%) and indicated excellent photocurrent stability. To further improve the structure/composition of the material, Wang's group
[124] applied metal-organic frameworks (MOFs) to the synthesis of CoNi alloys embedded within carbon nanocages (Co$\mathrm{Ni@CNTs-C)} \mathrm{by} \mathrm{incorporating} \mathrm{different} \mathrm{nickel} \mathrm{contents;} \mathrm{the}$ resulting products were then used as CEs in DSSCs. The optimal CoNi@CNTs-C-200 nanocages revealed better electroconductivity and catalytic performance than the others, including platinum. Sure enough, the best efficiency of $9.04 \%$ was obtained for CoNi@CNTs-C-200 compared to 7.88\% for platinum. Subsequently, Hou and coworkers [125] further investigated composites of NiCo alloys and MOFs (NiCo@C) as CEs of DSSCs. Spherical nanohybrids were synthesized by the solvothermal approach, which was followed by a calcining step. By comparing the resulting products, it was found that the $\mathrm{Co} / \mathrm{Ni}$ molar ratio effectively influenced their architectures and electrochemical properties. Particularly, hollow NiCo0.2@C microspheres showed excellent electron conduction and outstanding catalytic activity by virtue of their unique morphology and composition. What was noteworthy was that the best efficiency realized by using $\mathrm{NiCo}_{0.2} @ \mathrm{C}$ as the CE of DSSCs was 9.30\%, which was remarkably higher than the PCE of the cell based on platinum CE (8.04\%). This research would provide a potential option to selectively design and fabricate platinum-free CE materials with controllable structures and satisfying compositions.

\subsection{Cobalt- and iron-based alloys and compounds}

In view of the similarity in the unfilled valence states in the $d$ orbitals of the two metals, Co-Fe alloys and compounds have attracted much attention as catalysts. Recently, a range of binary Fe-Co nanofiber alloys with different stoichiometric ratios of iron and cobalt sources were designed and prepared by Tang's group [131] to function as electrocatalysts in DSSCs. The best PCE of 5.06\% resulted for the cell based on $\mathrm{FeCo}_{2}$ alloy CE. With the aim of further improving the electroconductivity and efficiency of Fe-Co alloys, Zhu et al. [137] encapsulated FeCo alloy with onion-like nitrogen-doped carbon (ONC@FeCo) via pyrolysis. The results of electrochemical measurements clarified that ONC@FeCo ensured fast electron transfer and tremendous electrocatalytic activity for the reduction of triiodide in the electrolyte. Notably, the DSSC with ONC@FeCo CE revealed a PCE of $8.26 \%$, which was comparable to that of the device based on platinum CE. The research certified that forming composites of FeCo alloy and carbon materials was a promising strategy to develop platinum-free CE materials with low cost and high efficiency.

As a characteristic magnetic material, $\mathrm{CoFe}_{2} \mathrm{O}_{4}$ has been brought into focus in the adsorption and catalysis fields $[138,139]$. However, there are limited papers that report on its electrocatalytic activity towards triiodide reduction as the $\mathrm{CE}$ of DSSCs. For example, Li and colleagues [132] reported the preparation of hollow $\mathrm{CoFe}_{2} \mathrm{O}_{4}$ particle-coated carbon nanotubes (h-CoFe $\mathrm{O}_{4} @ \mathrm{CNTs}$ ), which were first used as the CE in DSSCs (Fig. 6). With the addition of the conductive polypyrrole (PPy), the electrochemical measurements revealed that the as-prepared h-CoFe $\mathrm{O}_{4} @ \mathrm{CNTs} / \mathrm{PPy}$ showed promising electron transfer and catalytic properties, comparable to those of con- 


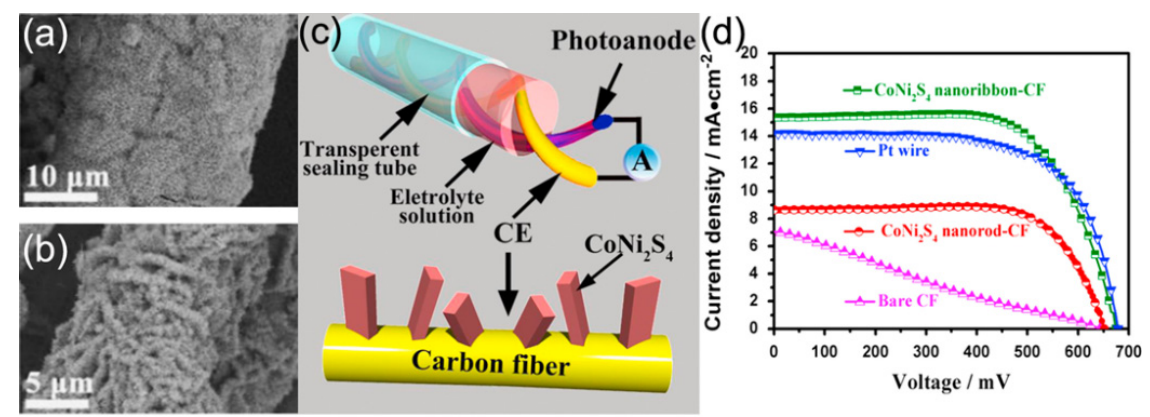

(e)

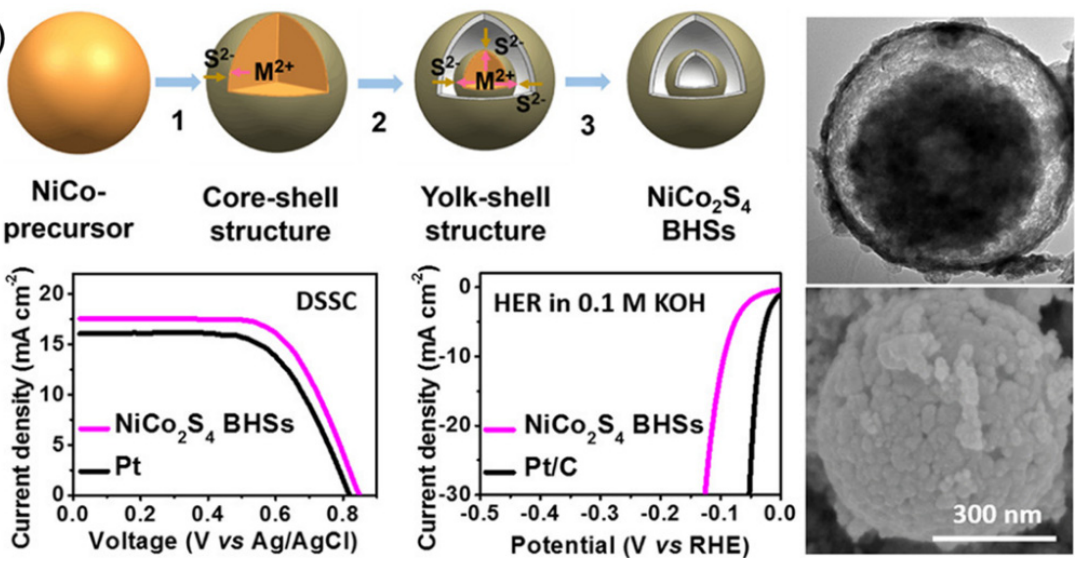

Fig. 6. SEM images of (a) $\mathrm{NiCo}_{2} \mathrm{~S}_{4}$ nanoribbons and (b) $\mathrm{NiCo}_{2} \mathrm{~S}_{4}$ nanorods grown on carbon fibers; schematic setup of the fiber-shaped DSSC. Reproduced from ref. [117]. (e) The fabrication process, electrocatalytic measurement results, and SEM and TEM images of $\mathrm{NiCo}_{2} \mathrm{~S}_{4} \mathrm{BHS}_{\text {. }} \mathrm{Reproduced} \mathrm{from}$ ref. [116].

ventional platinum. Ultimately, the best efficiency obtained was 6.55\% while using h-CoFe $\mathrm{O}_{4} @ \mathrm{CNTs} / \mathrm{PPy}$, which was almost identical to that of platinum (6.61\%). Following it, Co-Fe-S and $\mathrm{Co}-\mathrm{Fe}-\mathrm{Se}$ nanocubes with the diameter of about $150 \mathrm{~nm}$ were engineered by Qian and fellow workers [31]. Benefiting from their porous architectures and unique compositions, the resulting products exhibited low electrical resistance and high electrocatalytic activity. Compared with that of the precious platinum (8.16\%), Co-Fe-S or Co-Fe-Se nanomaterial presented a higher PCE, which was $9.06 \%$ or $9.58 \%$, respectively.

\subsection{Iron- and nickel-based alloys and compounds}

With both belonging to the first row of the transition series of elements, the similar atomic radii and electronic configurations of elemental nickel and iron possibly endow them with similar physical and chemical characteristics [140]. Hence, some researches have been devoted to employing Fe-Ni alloys and compounds as catalysts in water splitting. In 2014, Deng and coworkers [134] presented for the first time the preparation of an FeNi alloy encapsulated by pod-like nitrogen-doped carbon nanotubes $(\operatorname{Pod}(\mathrm{N})-\mathrm{FeNi})$ through pyrolysis method that acted as the CE. They expressed that the sealed FeNi nanoparticles modified the electronical properties of the carbon nanotubes, which gave rise to outstanding electrochemical performances of the resultant $\operatorname{Pod}(\mathrm{N})-\mathrm{FeNi}$. Photoelectrical measurements revealed that $\operatorname{Pod}(\mathrm{N})-\mathrm{FeNi}$ exhibited a higher PCE (8.82\%) than Pod-Fe (6.12\%) and CNTs (4.87\%), and even outperformed platinum (8.02\% PCE). This work opened up the possibility of applying FeNi alloys as CEs in DSSCs, but the requirements of high temperature and toxic reagents limited their development for large-scale synthesis for DSSCs. To overcome these problems, Sim et al. [135] synthesized a series of FeNi nanoparticles with different molar ratios that were deposited on GO-coated FTO by dry plasma reduction technique, which did not require high temperatures or toxic reagents. Benefiting from the synergistic effect of iron and nickel, the resulting nanohybrids displayed a high electrocatalytic activity. Although the cell using Fe0.7Ni0.3/RGO CE yielded the best efficiency, it was only $4.11 \%$. Lately, our group [136] fabricated spherical nickel iron sulfide with the aim of glucose ( $\left.\mathrm{Ni}_{0.5} \mathrm{Fe}_{0.5} \mathrm{~S}_{2} / \mathrm{C}\right)$ by using a novel hydrothermal approach. Profiting from the synergetic effect between nickel and iron, faster electron transfer and higher electrocatalytic activity were realized for the as-synthesized $\mathrm{Ni}_{0.5} \mathrm{Fe}_{0.5} \mathrm{~S}_{2} / \mathrm{C}$, compared to those of platinum. As expected, the cell based on $\mathrm{Ni}_{0.5} \mathrm{Fe}_{0.5} \mathrm{~S}_{2} / \mathrm{C}$ CE yielded a superior efficiency (6.74\%), compared to that of the device with platinum CE. This work could open a new window for the design of platinum-free CE materials.

\section{Conclusions and outlook}

The CE plays a vital role in improving the photovoltaic performance of a DSSC, as its function is to collect photoelectrons from the external circuit and catalyze the reduction of the electrolyte molecules. In this review, we provided a survey of the literature for the rapid development and performances of CCNI as CE materials, and compared the electrocatalytic activities of 

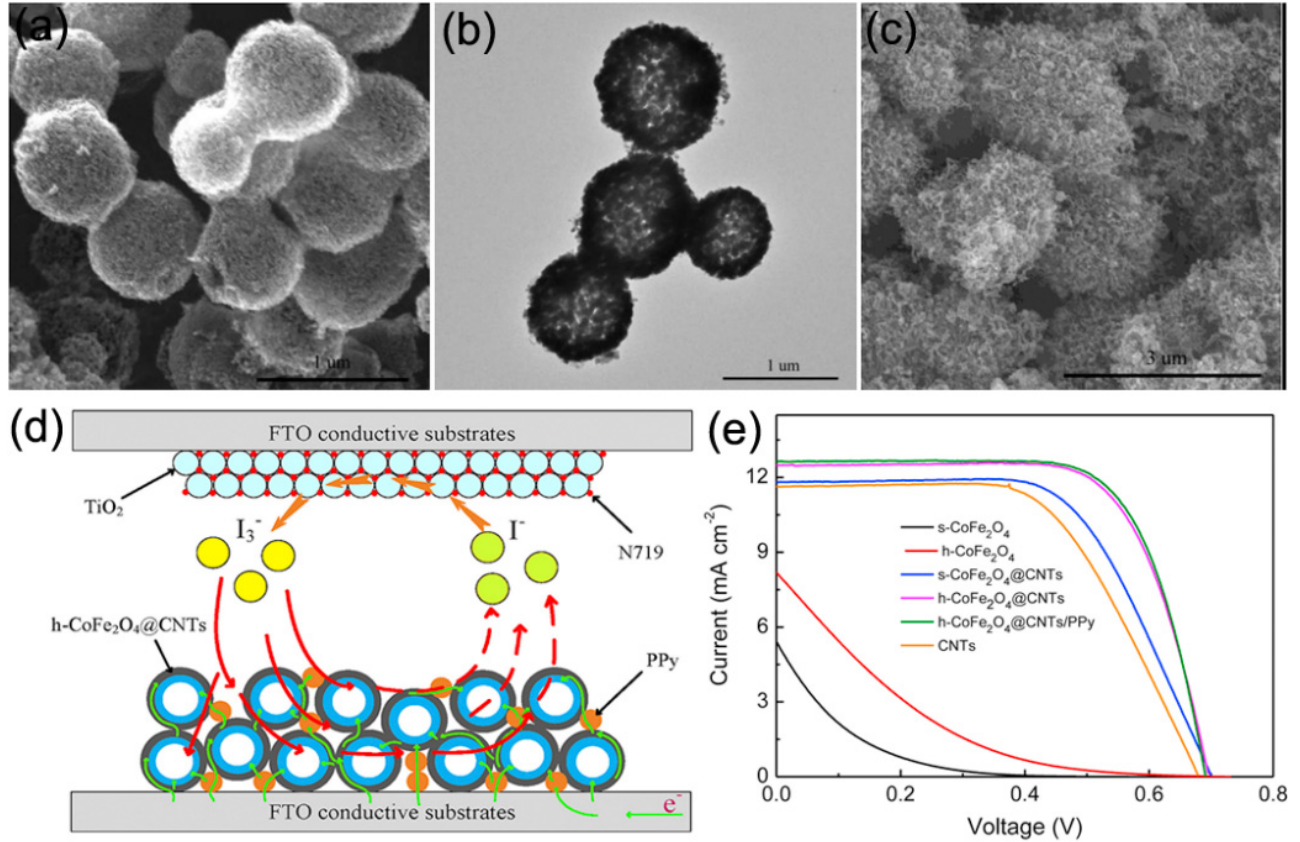

Fig. 6. (a, b) SEM and TEM images of h-CoFe $\mathrm{O}_{4}$; (c) SEM image of h-CoFe $\mathrm{O}_{4} @ \mathrm{CNTs}$; (d) Functional setup of a DSSC; (e) Photocurrent density-voltage plots of DSSCs with s-CoFe $\mathrm{O}_{4}, \mathrm{~s}-\mathrm{CoFe}_{2} \mathrm{O}_{4} @ \mathrm{CNTs}$, h-CoFe $2 \mathrm{O}_{4}, \mathrm{~h}-\mathrm{CoFe}_{2} \mathrm{O}_{4} @ \mathrm{CNTs}$, h-CoFe $\mathrm{O}_{4} @ \mathrm{CNTs} / \mathrm{PPy}$, and CNTs CEs. Reproduced from ref. [132].

their oxides, sulfides, and selenides. We have also summarized the various performance-optimization methods of promoting the electrocatalytic activity of CCNI. The performance optimization mainly focused on the effect of fabrication of architectures, composites with carbon materials, and elemental doping to enhance the charge transfer ability, obtain favorably active sites, and regulate their electronic construction for definitively boosting their photovoltaic performances.

In summary, earlier research mainly explored the availability of monometallic and pure compounds of iron, cobalt, and nickel. In subsequent studies, their bimetallic alloys and compounds have increasingly exhibited the potential to substitute the precious metal platinum. Through the design and realization of diverse optimization methods, the electrocatalytic performances of CCNI as CE materials have surpassed that of the standard platinum CE. Even though substantial progress has been achieved, there are still some shortcomings and problems with each type of CE in DSSCs. The electrochemical impedance of metal oxides in the electrode is large, and the intrinsic electrocatalytic performance is not as good as those of the sulphides and selenides. In addition, metal selenides exhibit more favorable electrical conductivity and intrinsic catalytic property owing to their smaller electronegativity metallicity, compared with those of metal sulfides. Although the selenides display excellent properties, the reaction elements need to be strictly controlled during the synthesis process. Besides, the mechanism of CCNI for electrocatalytic reduction of electrolyte molecules is still not clear. Particularly, the fundamental effect of elemental doping and using bimetals requires further investigation, and this will become an important research direction for CE materials.

\section{References}

[1] H. Yuan, J. Liu, H. S. Li, Y. F. Li, X. F. Liu, D. X. Shi, Q. Wu, Q. Z. Jiao, J. Mater. Chem. A, 2018, 6, 5603-5607.

[2] M. Chen, L. L. Shao, Z. Y. Yuan, Q. S. Jing, K. J. Huang, Z. Y. Huang, X. H. Zhao, G. D. Zou, ACS Appl. Mater. Interfaces, 2017, 9, 17949-17960

[3] P. Kulkarni, S. K. Nataraj, R. G. Balakrishna, D. H. Nagaraju, M. V. Reddy, J. Mater. Chem. A, 2017, 5, 22040-22094.

[4] S. L. Jian, Y. J. Huang, M. H. Yeh, K. C. Ho, J. Mater. Chem. A, 2018, 6, 5107-5118.

[5] I. P. Liu, H. Teng, Y. L. Lee, J. Mater. Chem. A, 2017, 5, 23146-23157.

[6] J. Azadmanjiri, V. K. Srivastava, P. Kumar, M. Nikzad, J. Wang, A. Yu, J. Mater. Chem. A, 2018, 6, 702-734.

[7] M. Chen, L. L. Shao, Z. M. Gao, T. Z. Ren, Z. Y. Yuan, J. Power Sources, 2015, 286, 82-90.

[8] B. O'Regan, M. Grätzel, Nature, 1991, 353, 737-740.

[9] A. Yella, H. W. Lee, H. N. Tsao, C. Yi, A. K. Chandiran, Md. K. Nazeeruddin, E. W. G. Diau, C. Y. Yeh, S. M. Zakeeruddin, M. Grätzel, Science, 2011, 334, 629-634.

[10] M. Freitag, J. Teuscher, Y. Saygili, X. Y. Zhang, F. Giordano, P. Liska, J. L. Hua, S. M. Zakeeruddin, J. E. Moser, M. Grätzel, A. Hagfeldt, Nat. Photonics, 2017, 11, 372-378.

[11] X. Zhang, J. W. Bai, M. M. Zhen, L. Liu, RSC Adv., 2016, 6, 89614-89620.

[12] Y. H. Wu, B. Zhou, C. Yang, S. C. Liao, W. H. Zhang, C. Li, Chem. Commun., 2016, 52, 11488-11491.

[13] M. Chen, L. L. Shao, Chem. Eng. J., 2016, 304, 629-645.

[14] M. Chen, L. L. Shao, X. Qian, T. Z. Ren, Z. Y. Yuan, J. Mater. Chem. C, 2014, 2, 10312-10321.

[15] X. Zhang, Y. X. Yang, S. Q. Guo, F. Z. Hu, L. Liu, ACS Appl. Mater. Interfaces, 2015, 7, 8457-8464.

[16] X. Zhang, T. Z. Jing, S. Q. Guo, G. D. Gao, L. Liu, RSC Adv., 2014, 4, 


\section{Graphical Abstract}

Chin. J. Catal., 2019, 40: 1282-1297 doi: S1872-2067(19)63361-9

Recent advances in cobalt-, nickel-, and iron-based chalcogen compounds as counter electrodes in dye-sensitized solar cells

Pengkun Wei, Xue Chen, Guizhu Wu, Jing Li, Yang Yang, Zeiwei Hao, Xiao Zhang *, Jing Li *, Lu Liu*

Nankai University; Civil Aviation University of China

As promising counter electrodes, chalcogen compounds of iron, cobalt, and nickel exhibit excellent electrocatalytic activities. Moreover, fabrication of architectures, regulation of the components, formation of composites with carbon materials, and elemental doping can effectively improve their electrochemical properties.

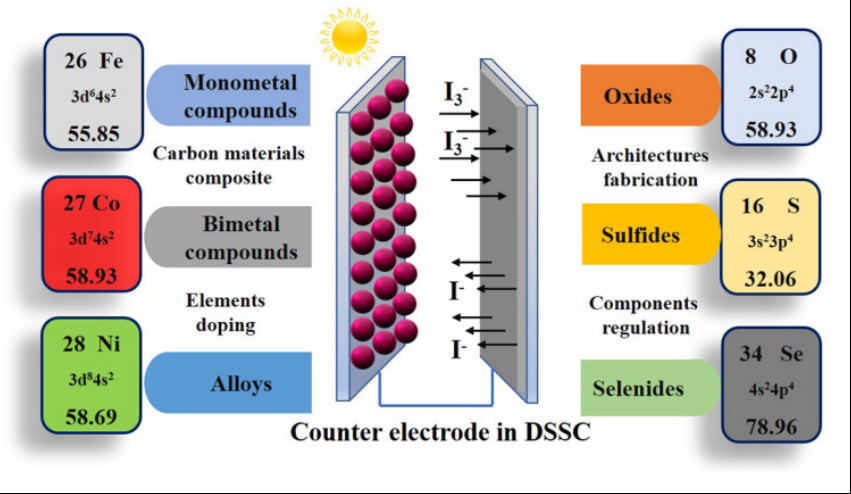

2013, 3, 16528-16533.

[36] Y. Y. Duan, Q. W. Tang, B. L. He, Z. Y. Zhao, L. Zhu, L. M. Yu, J. Power Sources, 2015, 284, 349-354.

[37] X. T. Yuan, H. X. Ge, X. Wang, C. L. Dong, W. J. Dong, S. R. Muhammad, Z. W. Xu, J. X. Zhang, F. Q. Huang, ACS Energy Lett., 2017, 2, 1208-1213.

[38] Y. Z. Zhang, Y. Wang, Y. L. Xie, T. Cheng, W. Y. Lai, H. Pang, W. Huang, Nanoscale, 2014, 6, 14354-14359.

[39] H. L. Wang, N. Mao, J. Shi, Q. G. Wang, W. H. Yu, X. Wang, ACS Appl. Mater. Interfaces, 2015, 7, 2882-2890.

[40] X. D. Cui, Z. Q. Xie, Y. Wang, Nanoscale, 2016, 8, 11984-11992.

[41] T. Liu, X. M. Mai, H. J. Chen, J. Ren, Z. T. Liu, Y. X. Li, L. Gao, N. Wang, J. X. Zhang, H. C. He, Z. H. Guo, Nanoscale, 2018, 10, 4194-4201.

[42] H. Yuan, Q. Z. Jiao, J. Liu, X. F. Liu, H. Y. Yang, Y. Zhao, Q. Wu, D. X. Shi, H. S. Li, J. Power Sources, 2016, 336, 132-142.

[43] J. H. Huo, J. H. Wu, M. Zheng, Y. G. Tu, Z. Lan, J. Power Sources, 2015, 293, 570-576.

[44] J. H. Huo, J. H. Wu, M. Zheng, Y. G. Tu, Z. Lan, Electrochim. Acta, 2016, 187, 210-217.

[45] E. B. Bi, H. Chen, X. D. Yang, W. Q. Peng, M. Grätzel, L. Y. Han, Energy Environ. Sci., 2014, 7, 2637-2641.

[46] X. H. Miao, K. Pan, G. F. Wang, Y. P. Liao, L. Wang, W. Zhou, B. J. Jiang, Q. J. Pan, G. H. Tian, Chem.-Eur. J., 2014, 20, 474-482.

[47] Y. D. Niu, X. Qian, J. Zhang, W. M. Wu, H. Y. Liu, C. Xu, L. X. Hou, J. Mater. Chem. A, 2018, 6, 12056-12065.

[48] V. Murugadoss, N. Wang, S. Tadakamalla, B. Wang, Z. H. Guo, S. Angaiah, J. Mater. Chem. A, 2017, 5, 14583-14594.

[49] I. T. Chiu, C. T. Li, C. P. Lee, P. Y. Chen, Y. H. Tseng, R. Vittal, K. C. Ho, Nano Energy, 2016, 22, 594-606.

[50] Y. B. Li, H. M. Zhang, Y. Wang, P. R. Liu, H. G. Yang, X. D. Yao, D. Wang, Z. Y. Tang, H. J. Zhao, Energy Environ. Sci., 2014, 7, 3720-3726.

[51] M. K. Datta, K. Kadakia, O. I. Velikokhatnyi, P. H. Jampani, S. J. Chung, J. A. Poston, A. Manivannan, P. N. Kumta, J. Mater. Chem. A, 2013, 1, 4026-4037.

[52] C. H. Cui, S. H. Yu, Acc. Chem. Res., 2013, 46, 1427-1437.

[53] Z. J. Tan, P. R. Liu, H. M. Zhang, Y. Wang, M. Al-Mamun, H. G. Yang, D. Wang, Z. Y. Tang, H. J. Zhao, Chem. Commun., 2015, 51, 5695-5697.

[54] S. Lu, Y. L. Wang, F. Li, G. C. Yang, H. Y. Yang, X. T. Zhang, Y. C. Liu, J. Phys. Chem. C, 2017, 121, 12524-12530.

[55] Y.-J. Huang, C.-P. Lee, H.-W. Pang, C.-T. Li, M.-S. Fan, R. Vittal, K.-C. 
Ho, Mater. Today Energy, 2017, 6, 189-197.

[56] C.-W. Kung, H.-W. Chen, C.-Y. Lin, K.-C. Huang, R. Vittal, K.-C. Ho, ACS Nano, 2012, 6, 7016-7025.

[57] J. C. Tsai, M. H. Hon, I. C. Leu, RSC Adv., 2015, 5, 4328-4333.

[58] H. Sun, L. Zhang, Z. S. Wang, J. Mater. Chem. A, 2014, 2, 16023-16029.

[59] Z. J. Tan, P. R. Liu, H. M. Zhang, Y. Wang, M. Al-Mamun, H. G. Yang, D. Wang, Z. Y. Tang, H. J. Zhao, Chem. Commun., 2015, 51, 5695-5697.

[60] X. Sun, J. Dou, F. Y. Xie, Y. F. Li, M. D. Wei, Chem. Commun., 2014, 50, 9869-9871.

[61] X. W. Wang, B. Batter, Y. Xie, K. Pan, Y. P. Liao, C. M. Lv, M. X. Li, S. Y. Sui, H. G. Fu, J. Mater. Chem. A, 2015, 3, 15905-15912.

[62] Y. B. Li, H. F. Wei, H. M. Zhang, P. R. Liu, Y. Wang, W. Q. Fang, H. G. Yang, Y. Li, H. J. Zhao, Chem. Commun., 2014, 50, 5569-5571.

[63] J. L. Zheng, W. Zhou, Y. R. Ma, W. Cao, C. B. Wang, L. Guo, Chem. Commun., 2015, 51, 12863-12866.

[64] Y. M. Xiao, G. Y. Han, H. H. Zhou, Y. P. Li, J. Y. Lin, Electrochim. Aata, 2015, 155, 103-109.

[65] Z. Q. Wan, C. Y. Jia, Y. Wang, Nanoscale, 2015, 7, 12737-12742.

[66] M. N. Lu, C. S. Dai, S. Y. Tai, T. W. Lin, J. Y. Lin, J. Power Sources, 2014, 270, 499-505.

[67] M. X. Guo, F. L. Zhao, Y. G. Yao, S. M. Wang, S. H. Yin, Electrochim. Acta, 2016, 205, 15-19.

[68] J. Kim, C. L. Jung, M. Kim, S. Kim, Y. Kang, H. S. Lee, J. Park, Y. Jun, D. Kim, Nanoscale, 2016, 8, 7761-7767.

[69] A. Sarkar, A. K. Chakraborty, S. Bera, Sol. Energy Mater. Sol. Cells, 2018, 182, 314-320.

[70] G. H. Guai, M. Y. Leiw, C. M. Ng, C. M. Li, Adv. Energy Mater., 2012, 2, 334-338.

[71] J. Y. Lin, W. Y. Wang, Y. T. Lin, S. W. Chou, ACS Appl. Mater. Interfaces, 2014, 6, 3357-3364.

[72] H. M. Chuang, C. T. Li, M. H. Yeh, C. P. Lee, R. Vittal, K. C. Ho, J. Mater. Chem. A, 2014, 2, 5816-5824.

[73] W. J. Ke, G. J. Fang, H. Tao, P. L. Qin, J. Wang, H. W. Lei, Q. Liu, X. Z. Zhao, ACS Appl. Mater. Interfaces, 2014, 6, 5525-5530.

[74] Y. P. Liao, K. Pan, Q. J. Pan, G. F. Wang, W. Zhou, H. G. Fu, Nanoscale, 2015, 7, 1623-1626.

[75] X. Zhang, H. J. Zhang, X. Y. Wang, X. M. Zhou, RSC Adv., 2018, 8, 28131-28138.

[76] L. Wang, Y. T. Shi, H. Zhang, X. G. Bai, Y. X. Wang, T. L. Ma, J. Mater. Chem. A, 2014, 2, 15279-15283.

[77] C. L. Zhang, L. B. Deng, P. X. Zhang, X. Z. Ren, Y. L. Li, T. S. He, Electrochim. Acta, 2017, 229, 229-238.

[78] S. S. Huang, Q. Q. He, W. L. Chen, Q. Q. Qiao, J. T. Zai, X. F. Qian, Chem.-Eur. J., 2015, 21, 4085-4091.

[79] W. J. Wang, X. Pan, W. Q. Liu, B. Zhang, H. W. Chen, X. Q. Fang, J. X. Yao, S. Y. Dai, Chem. Commun., 2014, 50, 2618-2620.

[80] S. S. Huang, Q. Q. He, W. L. Chen, J. T. Zai, Q. Q. Qiao, X. F. Qian, Nano Energy, 2015, 15, 205-215

[81] F. Liu, J. Zhu, L. H. Hu, B. Zhang, J. X. Yao, Md. K. Nazeeruddin, M. Graetzel, S. Y. Dai, J. Mater. Chem. A, 2015, 3, 6315-6323.

[82] L. Wang, Y. T. Shi, Y. X. Wang, H. Zhang, H. W. Zhou, Y. Wei, S. Y. Tao, T. L. Ma, Chem. Commun., 2014, 50, 1701-1703.

[83] H. Harrendrakrishnakumar, R. Chulliyote, M. G. Joseph, J. Solid State Electrochem., 2017, 22, 1-9.

[84] M. Awais, E. Gibson, J. G. Vos, D. P. Dowling, A. Hagfeldt, D. Dini, ChemElectroChem, 2014, 1, 384-391.

[85] H. C. Sun, D. Qin, S. Q. Huang, X. Z. Guo, D. M. Li, Y. H. Luo, Q. B. Meng, Energy Environ. Sci., 2011, 4, 2630-2637.

[86] W. S. Chi, J. W. Han, S. Yang, D. K. Roh, H. Lee, J. H. Kim, Chem. Commun., 2012, 48, 9501-9503.
[87] W. Zhao, T. Q. Lin, S. R. Sun, H. Bi, P. Chen, D. Y. Wan, F. Q. Huang, J. Mater. Chem. A, 2013, 1, 194-198.

[88] Z. L. Ku, X. Li, G. H. Liu, H. Wang, Y. G. Rong, M. Xu, L. F. Liu, M. Hu, Y. Yang, H. W. Han, J. Mater. Chem. A, 2013, 1, 237-240.

[89] Y. Li, Y. Chang, Y. Zhao, J. Wang, C. W. Wang, J. Alloys Compd., 2016, 679, 384-390.

[90] C. Q. Feng, Z. T. Jin, M. R. Zhang, Z. S. Wang, Electrochim. Acta, 2018, 281, 237-245.

[91] Y. Y. Duan, Q. W. Tang, B. L. He, R. Li, L. M. Yu, Nanoscale, 2014, 6, 12601-12608.

[92] J. B. Jia, J. H. Wu, Y. G. Tu, J. H. Huo, M. Zheng, J. M. Lin, J. Alloys Compd, 2015, 640, 29-33.

[93] H. Wu, Y. X. Wang, L. M. Zhang, Z. Y. Chen, C. Wang, S. H. Fan, J. Alloy. Compd., 2018, 745, 222-227.

[94] C. T. Lee, J. D. Peng, C. T. Li, Y. L. Tsai, R. Vittal, K. C. Ho, Nano Energy, 2014, 10, 201-211.

[95] F. Gong, X. Xu, Z. Q. Li, G. Zhou, Z. S. Wang, Chem Commun., 2013 49, 1437-1439.

[96] X. Zhang, J. W. Bai, B. Yang, G. Li, L. Liu, RSC Adv., 2016, 6, 58925-58932.

[97] R. Singh, S. Kumar, R. K. Bedi, V. Saxena, D. K. Aswal, A. Mahajan, J. Phys. Chem. Solids, 2018, 123, 191-197.

[98] Z. Q. Li, F. Gong, G. Zhou, Z.-S. Wang, J. Phys. Chem. C., 2013, 117, 6561-6566.

[99] J. Dong, J. H. Wu, J. B. Jia, L. Q. Fan, J. M. Lin, J. Colloid. Interface Sci,, 2017, 498, 217-222.

[100] Q.-L. Liu, Y.-J. Dong, Y. Cao, H.-Y. Chen, D.-B. Kuang, C.-Y. Su, Electrochim. Acta, 2017, 250, 244-250.

[101] Y. Hu, Z. Zheng, H. M. Jia, Y. W. Tang, L. Z. Zhang, J. Phys. Chem. C, 2008, 112, 13037-13042.

[102] S. Shukla, N. H. Loc, P. P. Boix, T. M. Koh, R. R. Prabhakar, H. K. Mulmudi, J. Zhang, S. Chen, C. F. Ng, C. H. A. Huan, N. Mathews, T. Sritharan, Q. H. Xiong, ACS Nano, 2014, 8, 10597-10605.

[103] J. Liu, Q. W. Tang, B. L. He, L. M. Yu, J. Power Sources, 2015, 275, 288-293.

[104] M. Batmunkh, A. Shrestha, G. Gao, L. P. Yu, J. Zhao, M. J. Biggs, C. J. Shearer, J. G. Shapter, Sol. RRL., 2017, 1, 1700011.

[105] D. Rickard, G. W. Luther III, Chem. Rev, 2007, 107, 514-562.

[106] H. X. Xu, C. J. Zhang, Z. W. Wang, S. P. Pang, X. H. Zhou, Z. Y. Zhang, G. L. Cui, J. Mater. Chem. A, 2014, 2, 4676-4681.

[107] J. W. Xiao, L. Wan, S. H. Yang, F. Xiao, S. Wang, Nano Lett., 2014, $14,831-838$

[108] Z. W. Shi, H. Lu, Q. Liu, K. Deng, L. Y. Xu, R. J. Zou, J. Q. Hu, Y. Bando, D. Golberg, L. Li, Energy Technol., 2014, 2, 517-521.

[109] X. Zhang, S. Q. Guo, M. M. Zhen, G. D. Gao, L. Liu, J. Electrochem. Soc., 2015, 162, H774-H779.

[110] C. L. Zhang, L. B. Deng, P. X. Zhang, X. Z. Ren, Y. L. Li, T. S. He, Dalton Trans., 2017, 46, 4403-4411

[111] F. Du, Q. Yang, T. Z. Qin, G. Li, Sol. Energy, 2017, 146, 125-130.

[112] Z. Y. Zhang, X. G. Wang, G. L. Cui, A. H. Zhang, X. H. Zhou, H. X. Xu, L. Gu, Nanoscale, 2014, 6, 3540-3544.

[113] J. Y. Lin, S. W. Chou, Electrochem. Commun., 2013, 37, 11-14.

[114] M. N. Lu, J. Y. Lin, T. C. Wei, J. Power Sources, 2016, 332, 281-289.

[115] R. Krishnapriya, S. Praneetha, A. M. Rabel, M. A. Vadivel Murugan, J. Mater. Chem. C, 2017, 5, 3146-3155.

[116] Y. Q. Jiang, X. Qian, C. L. Zhu, H. Y. Liu, L. X. Hou, ACS Appl. Mater. Interfaces, 2018, 10, 9379-9389.

[117] L. Chen, Y. Zhou, H. Dai, T. Yu, J. G. Liu, Z. G. Zou, Nano Energy, 2015, 11, 697-703

[118] S. Y. Khoo, J. W. Miao, H. B. Yang, Z. M. He, K. C. Leong, B. Liu, T. T. Y. Tan, Adv. Mater. Interfaces, 2015, 2, 1500384.

[119] Z. T. Jin, G. Y. Zhao, Z. S. Wang, J. Mater. Chem. C, 2018, 10 
3901-3909.

[120] L. Shao, X. Qian, H. M. Li, C. Xu, L. X. Hou, Chem. Eng. J., 2017, 315, 562-572.

[121] D. Chen, H. Zhang, Y. Liu, J. H. Li, Energy Environ. Sci., 2013, 6, 1362-1387.

[122] J. Wang, Q. W. Tang, B. L. He, P. Z. Yang, J. Power Sources, 2016, 328, 185-194.

[123] X. X. Chen, Q. W. Tang, B. L. He, L. Lin, L. M. Yu, Angew. Chem. Int. Ed., 2014, 53, 10799-10803.

[124] Z. Q. Xie, X. D. Cui, W. W. Xu, Y. Wang, Electrochim. Aata, 2017, 229, 361-370.

[125] X. C. Jiang, H. M. Li, S. L. Li, S. W. Huang, C. L. Zhu, L. X. Hou, Chem. Eng. J., 2018, 334, 419-431.

[126] Y. N. Wang, N. Q. Fu, P. Ma, Y. Y. Fang, L. M. Peng, X. W. Zhou, Y. Lin, Appl. Surf. Sci., 2017, 419, 670-677.

[127] K. S. Anuratha, S. Mohan, S. K. Panda, New J. Chem., 2016, 40, $1785-1791$.

[128] A.-L. Su, M.-N. Lu, C.-Y. Chang, T.-C. Wei, J.-Y. Lin, Electrochim. Acta, 2016, 222, 1410-1416.

[129] J. H. Huo, J. H. Wu, M. Zheng, Y. G. Tu, Z. Lan, J. Power Sources,
2016, 304, 266-272.

[130] F. X. Li, J. L. Wang, L. Zheng, Y. Q. Zhao, N. Huang, P. P. Sun, L. Fang, L. Wang, X. H. Sun, J. Power Sources, 2018, 384, 1-9.

[131] J. Liu, Q. W. Tang, B. L. He, J. Power Sources, 2014, 268, 56-62.

[132] H. Yuan, Q. Z. Jiao, S. L. Zhang, Y. Zhao, Q. Wu, H. S. Li, J. Power Sources, 2016, 325, 417-426.

[133] M. M. Zhang, J. T. Zai, J. Liu, M. Chen, Z. R. Wang, G. Li, X. F. Qian, L. W. Qian, X. B. Yu, Dalton Trans., 2017, 46, 9511-9516.

[134] X. J. Zheng, J. Deng, N. Wang, D. H. Deng, W.-H. Zhang, X. H. Bao, C. Li, Angew. Chem. Int. Edit., 2014, 53, 7023-7027.

[135] E. Sim, V. D. Dao, H. S. Choi, J. Alloys Compd., 2018, 742, 334-341.

[136] P. K. Wei, X. M. Li, J. Li, J. W. Bai, C. J. Jiang, L. Liu, Chem.-Eur. J., 2018, 24, 19032-19037.

[137] C. Y. Zhu, F. Xu, J. Chen, H. H. Min, H. Dong, L. Tong, K. Qasim, S. L. Li, L. T. Sun, J. Power Sources, 2016, 303, 159-167.

[138] M. Fu, Q. Z. Jiao, Y. Zhao, H. S. Li, J. Mater. Chem. A, 2013, 2, 735-744.

[139] J. Y. Park, G. A. Somoriai, Catal. Lett., 2016, 146, 1-11.

[140] M. S. Faber, M. A. Lukowski, Q. Ding, N. S. Kaiser, S. Jin, J. Phys. Chem. C, 2014, 118, 21347-21356.

\title{
钴、镍、铁基氧族化合物用作染料敏化太阳能电池对电极的研究进展
}

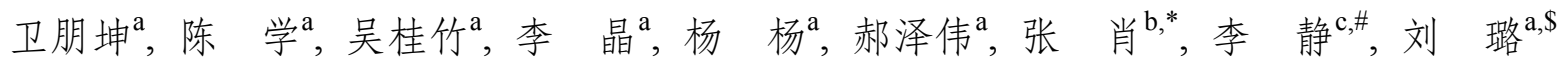 \\ a南开大学环境科学与工程学院, 天津市城市生态环境修复与污染防治重点实验室, 天津 300350 \\ b 中国民航大学飞机防火与应急研究所, 天津 300300 \\ c南开大学外国语学院, 天津 300350
}

摘要: 随着能源危机的加剧, 开发清洁、高效、可持续的太阳能已成为全球研究热点. 基于光伏收集转化太阳能为电能的 技术提供了一种极具潜力的解决方案. 此外, 得益于弱光响应力、环境友好及低制造成本等, 染料敏化太阳能电池(DSSC) 被认为是最具有应用前景的光伏技术之一. 通常, DSSC由纳米半导体氧化物(光阳极)、对电极、染料分子和氧化还原电解 质组成. 各组分的主要作用如下: 染料分子作为敏化剂, 吸收太阳光, 将激发的电子注入半导体氧化物的导带中, 使染料处 于氧化状态; 注入电子从半导体转移到导电玻璃和外部电路; 对电极中的电活性物质从外部电路中收集电子并转移到电 解液中, 实现电解液中氧化还原物质的催化还原; 电解液负责转移电子并还原氧化态的染料, 使染料转化为基态实现再生.

作为DSSC的主要组成部分, 对电极对提高DSSC的光伏性能起着至关重要的作用. 本文综述了近年来国内外关于钴、

镍、铁等金属氧族化合物作为对电极材料的研究进展和性能, 并对其氧化物、硫化物和硒化物的电催化活性进行了比较. 总结了提高该类对电极材料电催化活性的各种优化方法. 性能优化主要集中在结构调控、碳材料复合和元素掺杂等方面 的研究, 用以增强电荷转移能力, 获得良好的活性位点, 调节其电子结构, 最终提高光伏性能.

通过调研发现, 前期的研究主要是探索钴、镍、铁等金属的单金属化合物的可用性, 在后续的研究中, 其双金属合金及 其化合物越来越显示出替代贵金属铂的应用潜力. 通过多种优化方法的设计与实践发现,含有钴、镍、铁金属元素的化合 物作为对电极材料的电催化性能已超过标准的铂电极. 虽然DSSC的研究已经取得了较为深入的进展, 但各类型的对电极 材料在DSSC中都存在一些不足和问题. 对比发现, 金属氧化物在电极中的电化学阻抗较大, 本征电催化性能不如硫化物 和硒化物. 此外, 与金属硫化物相比, 金属硒化物具有更好的导电性和催化活性, 这得益于更小的电负性金属丰度. 硒化物 虽然具有优良的性质, 但在合成过程中需要严格控制反应条件. 此外, 其电催化还原电解质分子的催化机理尚不清楚. 特 别是元素掺杂和双金属的根本性效应需要进一步研究, 这也将成为对电极材料的重要研究方向.

关键词: 对电极; 染料敏化太阳能电池; 氧族化合物; 钴; 镍; 铁

收稿日期: 2018-12-27. 接受日期: 2019-03-15. 出版日期: 2019-09-05.

*通讯联系人. 电子信箱: xiao890829@126.com

\#通讯联系人. 电子信箱: victorjane@nankai.edu.cn

通讯联系人. 电子信箱: liul@nankai.edu.cn

基金来源: 国家自然科学基金杰出青年科学基金(21425729); 国家水污染防治专项科技项目(2017ZX07107002); 中国博士后科学 基金(2018M640209)，天津市科技支撑重点项目(18YFZCSF00500).

本文的电子版全文由Elsevier出版社在ScienceDirect上出版(http://www.sciencedirect.com/science/journal/18722067). 